\title{
UNDERSTANDING THE EFFECTS OF URBAN DESIGN ON URBAN WELLBEING
}

\author{
by
}

Michael Janik

Honours Bachelor of Sociology, Queen's University, 2016

A Major Research Paper

Presented to Ryerson University

in partial fulfilment of the requirements for the degree of

Master of Planning

in

Urban Development

Toronto, Ontario, Canada 2019

(C) Michael Janik, 2019 


\section{AUTHOR'S DECLARATION FOR ELECTRONIC SUBMISSION OF A MRP}

I hereby declare that I am the sole author of this MRP. This is a true copy of the MRP, including any required final revisions.

I authorize Ryerson University to lend this MRP to other institutions or individuals for the purpose of scholarly research.

I further authorize Ryerson University to reproduce this MRP by photocopying or by other means, in total or in part, at the request of other institutions or individuals for the purpose of scholarly research.

I understand that my MRP may be made electronically available to the public. 


\begin{abstract}
$\underline{\text { ABSTRACT }}$
This major research paper examines the relationship between urban design and wellbeing in an urban context. Urban wellbeing is analyzed across the built environment features of urban greenery, walkability, and density, and examined through the wellbeing dimensions of mental health, physical health, and social capital. Through a major literature review, this research highlights urban design elements and built form typologies that are strongly linked with improved wellbeing amongst urban residents. The literature also informs the analysis of two City of Toronto Secondary Plans and evaluates whether, and how, the policies address urban wellbeing through urban design.
\end{abstract}

Key words: urban design, urban wellbeing, health, social capital, greenery, walkability, density 


\section{ACKNOWLEDGEMENTS}

I would first like to acknowledge having the opportunity to carry out my MRP in Tkaronto. I acknowledge the land I live on today is the traditional territory of many nations, including the Huron-Wendat and Petun First Nations, the Seneca, and the Mississaugas of the Credit River. This sacred land has been a site of human activity for 15,000 years, and it is still home to many diverse First Nations, Inuit, and Metis peoples from across Turtle Island. I am grateful to have been born and raised on this territory, to be able to work in the community, and to have the opportunity to contribute to a happier, healthier, and more socially connected Toronto.

I must thank Michelle and Val for checking up on me through this whole process. They put up with me more than anyone should ever have to, but I owe so much of the last four months to their endless care and support. I would also like to thank Madison for her constant reassurance, for the times she calmed me down after I left an MRP meeting shaking with frustration and panic, and for always reminding me that I am stronger than I give myself credit for. Of course, I also need to commend lofi hip hop radio - beats to relax/study to for being the soundtrack behind 95\% of this MRP. And lastly, I would like to pat myself on the back for making this work come true. As important as this research topic is to me, there were many moments where I lost sight of why I was doing this in the first place. To the publisher from the University of Toronto that insinuated I would inevitably drop out studying something as vacuous and intangible as wellbeing, I'm happy to prove you wrong. I made it happen, and I am so proud of myself for doing so. 


\section{DEDICATION}

To a brighter tomorrow full of endless wonder and bigger dreams. 


\section{TABLE OF CONTENTS}

Chapter One: Outlining Urban Wellbeing 1

Framing a Definition of Urban Wellbeing 3

Definitions 6

Methodological Approach 9

Chapter Two: Literature Review 11

Stresses to Urban Wellbeing $\quad 12$

Urban Greenery 17

Mental Health 17

Physical Health 19

Social Capital 21

Walkability 24

Physical Health 24

Social Capital 27

Density $\quad 30$

Mental Health $\quad 30$

Social Capital $\quad 33$

Summary $\quad 37$

Chapter Three: Content Analysis $\quad 39$

Conclusion 62

Appendix $\quad 64$

References $\quad 66$ 


\section{CHAPTER ONE: Outlining Urban Wellbeing}

In 1855, English physician John Snow published the second edition of his investigation On the Mode of Communication of Cholera after London's third major cholera outbreak. He successfully linked the disease's spread to contaminated water supplies and dismissed the myth of miasma (Snow 1855). More significantly, Snow became the first to formally establish that the design, form, amenities, and utilities of cities impact the health of their residents. Simply said, Snow is widely acknowledged as the first to recognize the role that urban planning plays in enhancing urban health and wellbeing. The two disciplines drifted apart through most of the 20th century, but their reconnecting is becoming evermore important (Koohsari, Badland, and GilesCorti 2013), as the increase in healthy city strategies in many cities around the world suggests.

Compared to suburban and rural contexts, today's dense urban environments can be mentally and physically overwhelming for their residents (Smith 2018). The ill-being that city life can produce has been widely explored in the literature. For instance, Canadian planning consultant Todd Litman (2018) noted that urban residency increases the risk of psychosis, mood disorders, and substance abuse. Similarly, psychologist and professor Kalpana Srivastava (2009) linked urban environmental adversities to severe depression, family disintegration, and alienation. Along similar lines, King's College London psychological research team Newbury, Arseneault, Caspi, Moffitt, Odgers, and Fisher (2016) found that growing up in the city nearly doubled the likelihood of psychotic symptoms amongst children. Epidemiological studies have also documented how the physical and social characteristics of a city interact to produce either wellbeing or ill-being, and urban design has been identified as directly contributing to the wellbeing of urban residents (Joffe and Smith 2016). 
A recent report by the University of British Columbia and McGill University concluded that Toronto is one of Canada's unhappiest cities (Helliwell, Shiplett, and Barrington-Leigh 2018). Based on an analysis of 400,000 people, the study found that denser urban centres are home to the most dissatisfied because it is more difficult to craft a sense of togetherness and community that could more easily be found in small towns. With over 7,500 new residents moving to Downtown Toronto annually and a projected Downtown population of 475,000 by 2041 - double the Downtown population in 2016 (City of Toronto 2019) - it is critical that Toronto engages with strategies for wellbeing. This MRP will produce an English literature review of urban design factors and strategies influencing urban wellbeing, ${ }^{1}$ and will compare and contrast them with how the City of Toronto approaches the relationship between urban design and wellbeing by examining the York University Secondary Plan and Yonge-Eglinton Secondary Plan. In doing so, this MRP seeks to highlight urban design characteristics that support improved wellbeing and examine if and how City of Toronto urban design policies reference design elements that the literature links to improved wellbeing.

For some, the push for a higher density environment is welcomed. Vibrant pedestrian life, a variety of shops and services in close proximity, and the ability to lead more of one's life on foot are all enticing. Some authors argue that people are happiest in cities (Glaeser 2011), others argue that some cities have not become any happier over time (Easterlin 1974), and some argue that people are, on average, the least happy in cities (Berry and Okulicz-Kozaryn 2011). While some urban residents are being driven out of cities for financial reasons, others are leaving to improve their mental health. The anxiety and emotional exhaustion found in city life is

\footnotetext{
${ }_{1}^{1}$ See definition below.
} 
amounting to, what is quite simply, an unprecedented wave of burnout (Smith 2018). Humans evolved living in small groups of around 100 to 150 people, and researchers note that the physical stress of crowding, including noise, can trigger powerful and harmful psycho-physical stress responses (Smith 2018).

Urban design cannot solely account for these stimuli, but the way built environments are constructed continues to play a key role in the fundamental experience of place (Leyden, Goldberg, and Michelback 2011). There are many built environment interventions available to help foster pleasant and active street-scale experiences across neighbourhoods and communities, and through them, urban residents can reap the benefits of design for wellbeing (Mehta 2009). With $68 \%$ of the world's population expected to live in urban areas by 2050 (UN 2018), it is imperative that the design of our cities helps mitigate between increasingly dense urban forms and wellbeing.

\section{Framing a Definition of Urban Wellbeing}

In all its complexity, 'urban wellbeing' is patently difficult to wrangle. Its many possible definitions lack conformity and range from academic scientific interpretations to a social and cultural construction. Ultimately, there are no uncontested biological, spiritual, social, economic, or any other kind of markers for wellbeing (Ereaut \& Whiting 2008). However, the World Health Organization (WHO) has developed a well-accepted definition of health that can act as a point of departure for framing out urban wellbeing: it defines health as "a state of complete physical, mental, and social well-being and not merely the absence of disease or infirmity" (WHO 2006:1). From this perspective, urban planning (and urban design in particular) are important 
factors to the extent that the built environment of cities might facilitate or hinder people's ability to achieve such state of wellbeing in urban contexts.

Even though the healthy cities movement was established more than 30 years ago, its aims and approaches are more important than ever. From the beginning, its goal was not to promote particular actions but rather to advocate continuous improvement: "[a] healthy city is one that is continually creating and improving those physical and social environments and expanding those community resources which enable people to mutually support each other in performing all the functions of life and developing to their maximum potential" (WHO 1998). As such, striving for better health outcomes is a constant process of improvement and one that every urban resident has a stake in. These two WHO definitions generally reference high-level health factors, but the notion of wellbeing becomes a much more multi-layered issue when situated in an urban context. According to the literature reviewed in this MRP, harm to urban wellbeing can be manifested and measured across a spectrum of strains. The diagram on the following page captures some of the factors contributing to ill-being. 
Major Influences of Urban Ill-being

Source: Developed by the author

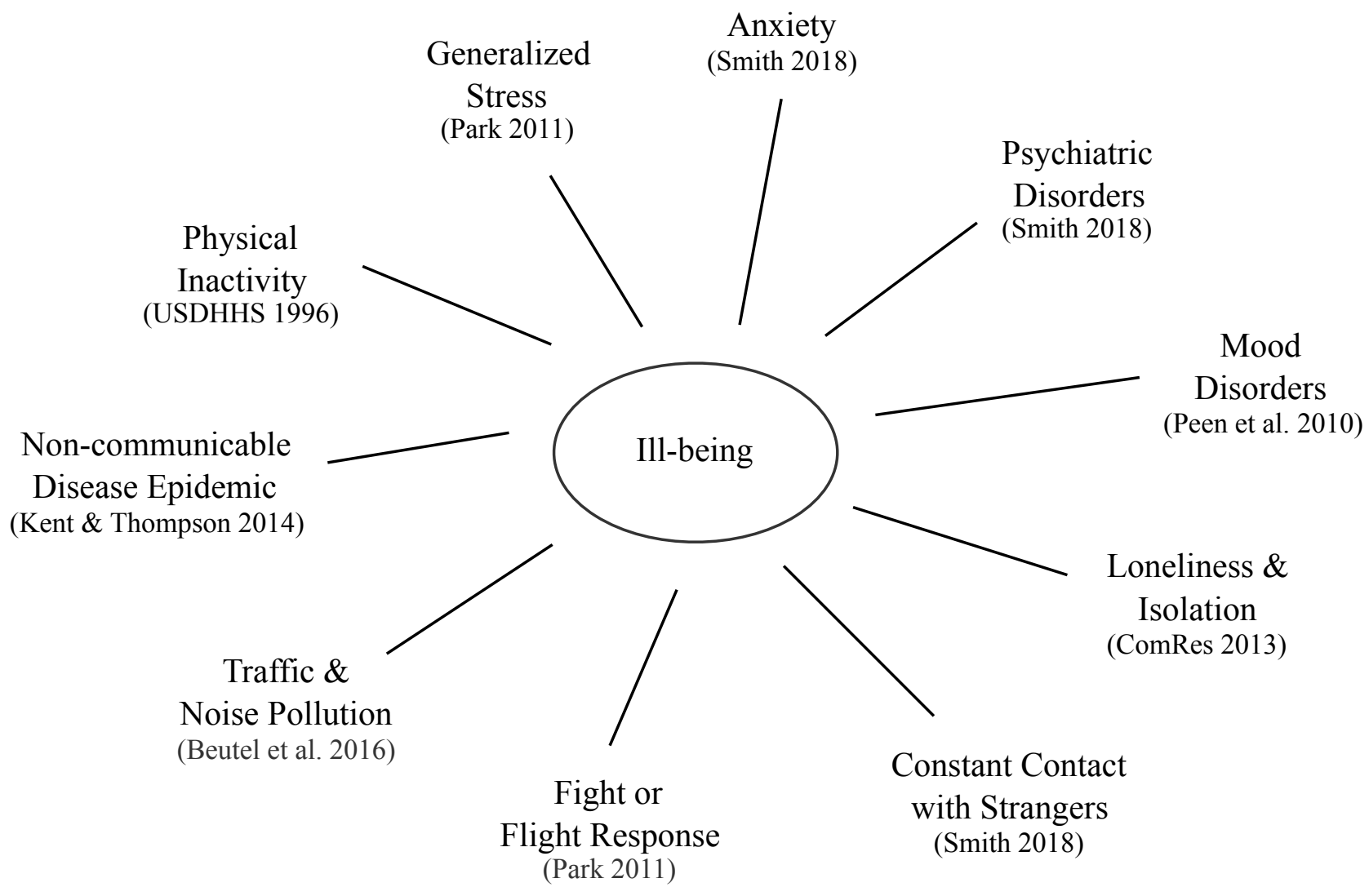

The diagram suggests that ill-being in an urban context is linked to the negative influence of mental, physical, and social stresses. Lansing and Marans (1969) wrote that an urban environment of high quality conveys a sense of wellbeing and satisfaction to its population through characteristics that may be physical, social, or symbolic. Contrastingly, Pacione (2003) contends that urban quality is not an attribute inherent in the environment, but is a behaviourrelated function of the interaction of environmental characteristics and person characteristics. Pacione reminds us that we must consider both 'the city on the ground and the city in the mind' (2003:20). The form of things physically translates environmental effects onto the person, 
and as such, planners and designers must consider how the uses and behaviours designed into an urban environment are embodied by those who engage with it.

Building directly on the WHO definition, in the context of this MRP 'urban wellbeing' is understood as a state of good physical, mental, and social wellbeing amongst urban residents. I take this definition as a point of departure to explore how certain aspects of the built environment that planners and urban designers can intervene/manage might contribute to urban wellbeing. I focus on three aspects of the built environment that the literature on urban wellbeing identifies as having a strong positive influence on the mental health, physical health, and social capital of urban residents: greenery, walkability, and density. Later, a Content Analysis of two Secondary Plans in Toronto will assess the extent to which these three aspects are referenced or not in municipal planning documents. As I elaborate in the Methodological Approach section, the analysis will also consider whether any explicit connections to urban wellbeing are made when greenery, walkability, and density are referenced in the Secondary Plans.

\section{Definitions}

'Urban greenery,' 'walkability,' and 'density' are all frequently referenced as key elements of the physical environment that have an influence on people's wellbeing in urban contexts. Authors typically reference one or two of these features in their works as relevant to understanding the relationship between urban design and urban wellbeing. Because these three features were independently and consistently referenced as relevant to urban wellbeing throughout the literature, they have been grouped together for this MRP. As such, their relevance as it pertains to this MRP must be initially framed. 'Social capital' must also be defined, as it is an essential 
component of urban wellbeing and is informed by the aforementioned influences. While urban greenery, walkability, and density are built environment interventions with an implication for wellbeing, social capital is an indicator for wellbeing. These concepts are salient amongst the scholars that research the relationship between urban wellbeing and urban design, and they will consequently be referenced heavily throughout this MRP.

\section{Urban Greenery}

According to the City of Toronto, 'green space' refers to a wide variety of natural and landscaped areas, both publicly and privately owned. "It includes parks, ravines, school yards, private yards, street trees, landscaped open spaces along streets and around buildings, cemeteries and green roofs" (City of Toronto 2015:1). While there may be subtle qualitative differences between these settings, these terms are used interchangeably for the purpose of this MRP and will be collectively referred to as urban greenery.

\section{Walkability}

The term 'walkable' has been in use since at least the eighteenth century, but in contrast, 'walkability' is a much more recent term that is relatively rarely defined in dictionaries (Forsyth 2015). Ann Forsyth, professor of urban planning and urban sociability researcher, argues that walkability has several dimensions and thematic definitions (Ibid). The first cluster of themes define a walkable environment as readily traversable, compact, safe for walking (both from perceptions of crime and actual traffic safety), and physically enticing with appropriate pedestrian infrastructure. The second set of definitions relate to perceived outcomes of walking 
and treat walkability as a means of achieving both the environmental preservation and social equity components of sustainable urban form through sustainable transportation options. This is facilitated through an exercise-inducing environment with features that encourage higher levels of walking and, subsequently, create an attractive environment that is lively and sociable. Lastly, walkability is used as a proxy for better design - a holistic solution to improving urban areas through slower paced, more human scaled, healthier, and happier design. "This encompasses many of the other definitions in an integrated package that is less about walking as such and more about a generally good pace to be" (Ibid, 276). For the purpose of this MRP, walkability will refer to urban built form where it is convenient for a city resident to access a majority of their day-to-day needs on-foot.

\section{Density}

Urban density can be measured and expressed in a variety of ways. The Growth Plan for the Greater Golden Horseshoe, 2006 mandates that urban growth centres will be planned to achieve, by 2031 or earlier, a minimum gross density target of 400 residents and jobs combined per hectare for each of the urban growth centres in the City of Toronto (2006:16). For the context of this MRP, 'density' will refer to urban areas of high population density. This is a measure of the intensity of land use, assuming that where land use is most intense additional consideration must be given to the public realm's urban design to mitigate any ill-being such dense environment might encourage.

\section{$\underline{\text { Social Capital }}$}


In his seminal book Bowling Alone, American political scientist Robert Putnam refers to social capital as connections among individuals and the social networks and norms of reciprocity and trustworthiness that arise from them (Putnam 2000). Urban studies and public health researcher Kevin Leyden echoes this sentiment, defining social capital as the social networks and interactions that inspire trust and reciprocity among citizens. "Individuals with high levels of social capital tend to be involved politically, to volunteer in their communities, and to get together more frequently with friends and neighbours. They are also more likely to trust or to think kindly of others" (Leyden 2003:1546). Social capital is also broadly related to experiential outcomes in the urban form, including: "pride in and attachment to the neighbourhood; social interaction; safety or security; perceived quality of the local environment; satisfaction with the home; stability; and participation in civic activities" (Kyttä, Haybatollahi, and Schmidt-Thomé 2016:35). For the context of this MRP, social capital will refer to an urban resident's ability to maintain social relationships, casually interact with other members of their community, and engage with their neighbourhood's events, activities, and public spaces.

\section{Methodological Approach}

This MRP is concerned with city design principles, primarily in the global north, and seeks to identify urban design interventions that are most strongly linked with improved urban wellbeing. In order to explore this relationship, this inquiry is guided by two research questions:

(1) What urban design factors and strategies most positively influence urban wellbeing?

(2) Are the City of Toronto's Secondary Plans consistent with the literature, and are their design goals engrained and operationalized to improve wellbeing? 
In order to answer the first research question, this MRP will begin with an in-depth literature review of urban health and wellbeing studies that reference the effects of urban design and built form. The literature suggests that there are three very important built environment features that have a strong impact on wellbeing: (1) urban greenery, (2) walkability, and (3) density. The literature review will break down how each of these interventions impact wellbeing across the dimensions of (1) mental health, (2) physical health, and (3) social capital. These built environment features were chosen because preliminary review highlights these characteristics as having a direct, positive impact on urban wellbeing. Similarly, these dimensions of wellbeing were chosen because urban design interventions in the literature tend to be evaluated by how they improve either personal health or social capital. For the second research question, I will examine the York University Secondary Plan and Yonge-Eglinton Secondary Plan. They are the enforceable sub-documents of the City of Toronto's Official Plan that guide development and contribute to shaping the built environment, and I will see if they engage with the discussion on urban design and wellbeing expressed through the built form features and health dimensions. This content analysis will highlight what components of wellbeing the City emphasizes through its Secondary Plans, if the Plans have different approaches for different neighbourhoods, and how rigorous and enforceable the Secondary Plans' actions are. My rationale and justifications for choosing these two particular Secondary Plans is provided later on in the MRP's Secondary Plan Content Analysis Methodology section. These Secondary Plans will be analyzed according to how directly they link their objectives with the built form concepts of urban greenery, walkability, and density, as well as the dimensions of mental health, physical health, and social capital. 


\section{CHAPTER TWO: Literature Review}

Academic efforts from sociologists, epidemiologists, architects, philosophers, and of course, urban designers and planners, try to wrangle the breadth of urban wellbeing, but ultimately, there has not been a single comprehensive examination of the topic. There are many intangible parameters at play, like social capital and mental health, and numerous complementary physical typologies and characteristics that have been found to correlate to urban wellbeing. Each component plays a mutually reinforcing role in urban wellbeing.

Preliminary research suggested that the dimensions of mental health, physical health, and social capital are substantially relevant to urban wellbeing, and as such, the deeper literature analysis is organized around them. The vast majority of the examined literature highlights urban greenery, walkability, and density as the three built environment features with the biggest potential to affect urban wellbeing/ill-being. It is broadly agreed that greenery enhances the built environment, improved walkability inspires city dwellers to physically engage with their communities through active transportation, and that a dense urban form generally offers more opportunities to engage in social interaction and strengthen one's social capital (Leyden et al. 2011, Mouratidis 2018). Together, these principles draw more people out into an enticing public realm, encourage active enjoyment, and create opportunities for interpersonal interaction on the streets to ultimately strengthen social capital (Mehta 2009). Through a closer examination of these factors, I will discuss how the literature suggests they can come together to hone an urban environment that is conducive to improved wellbeing. These findings will then inform the examination of the City of Toronto's York University Secondary Plan and Yonge-Eglinton Secondary Plan and how they address the link between urban design and urban wellbeing. 


\section{Stresses to Urban Wellbeing}

Drawn by a metropolitan lifestyle and employment opportunities, moving to the city has long been a rite of passage for young people. Recently however, a new yuppie narrative is being woven. 2018 US Census data showed that for the past five years in a row, the population of millennials in US cities like Los Angeles and Boston had fallen and population growth in big cities had shrunk (Smith 2018). In 2017, the number of people leaving London also reached a five-year high (Ibid). In a Vice interview on millennial urban flight, 28-year-old Londoner Sarah Graham said, "[we] were planning on leaving London at some point, anyway ... but the move was definitely catalyzed by my anxiety. I was finding it increasingly stressful ... I wasn't sleeping well, and feeling very anxious in big crowds of people" (Ibid, 1). Graham moved to the suburb of Hertfordshire and noted immediate improvement to her wellbeing: "[my] sleep instantly improved. I feel totally relaxed walking around on my own ... [it's a] much friendlier and more laid-back environment, lots of green spaces, and a real sense of community [that I] really appreciate now that I have it" (Ibid).

Many people understand that city life can be stressful: a Dutch study on the urban-rural differences in psychiatric disorders found that those living in cities were 21 percent more likely to experience an anxiety disorder and carried a 39 percent increased risk of mood disorders (Peen et al. 2010). A German study looked at the effects of long-term exposure to noise in urban environments and concluded that 'strong noise annoyance' is associated with a twofold higher prevalence of depression and anxiety amongst the general population (Beutel et al. 2016). Experimental psychologist Colin Ellard says that "[the] second psychological liability of city life comes from being in constant contact with strangers. This state of affairs can lead to feelings of 
social isolation and loneliness, and then of course have mental health consequences" (Smith 2018:2). Even though cities are full of people, living anonymously alongside millions of others can actually leave urban dwellers feeling isolated. For example, a 2013 survey by public research and communications firm ComRes commissioned by the $\mathrm{BBC}$ found that London is the loneliest place in the UK. After interviewing 2,598 English adults, 31\% of Londoners responded that they sometimes, regularly, or constantly felt lonely (ComRes 2013).

An international study by researchers at the University of Heidelberg and the Douglas Mental Health University Institute at McGill University reported that city dwellers' brains have a more sensitive, hair-trigger response to stressful or threatening situations compared with those living in suburban or rural areas. After conducting a stress test on volunteers while their brains were imaged by MRI, the researchers concluded that "it is the social aspects of urban living stress of living and dealing with lots of people, and feeling more anxiety, fear, and threat as a result - more so than other urban factors like pollution or noise" that explains the stronger stressrelated brain responses from city dwellers (Park 2011:2). Although one could speculate that the more people were faced with stress, the more they might become immune to them, the new findings suggest that even after years of city-living, people remained highly alert and anxious, indicating that the stresses of city life may be both constant and diverse and not easy to adapt to. There is also mounting concern about rising rates of serious physical conditions, particularly cancer, heart disease, and diabetes in urban populations. Australian planners and professors Jennifer Kent and Susan Thompson (2014) posit that many such non-communicable diseases have reached epidemic proportions in major cities, affecting people of all ages, nationalities, and classes. Across Norway and the Netherlands, a recent population-based health 
survey evaluated the health impact of long-term exposure to both traffic noise and air pollution, both as byproducts of city roadways. The study examined the following biological markers in the blood of 144,082 adults: blood sugar levels - associated with heart disease, diabetes, and stroke when elevated; C-reactive protein (CRP) - a protein that signals inflammation and can lead to heart disease; and lipids and triglycerides - linked to heart attacks when found in high levels (Cai et al. 2017). Using a $60 \mathrm{~dB}$ standard, the volume of a typical conversation, the study found that an increase of $5 \mathrm{~dB}$ in neighbourhood noise levels was linked to 0.3 percent higher blood sugar levels when compared to quieter neighbourhoods (Ibid). Increases in air pollution also showed a link: a $10 \mu \mathrm{g} / \mathrm{m}^{3}$ increase in air pollution levels was associated with 2.3 percent higher blood sugar levels, a 2.6 percent increase in CRP levels, and a 10 percent increase in triglycerides. These effects were independent of traffic noise and suggest that both noise and air pollution matter for health (Ibid).

A review of the relationships between physical activity and health conducted by the US Surgeon General concluded that substantial health gains could be achieved if all persons included moderate physical activity in their daily lives (US Department of Health and Human Services [USDHHS] 1996). 'Moderate activity' was defined as including thirty minutes of brisk walking or biking, fifteen minutes of jogging, or thirty to forty-five minutes of gardening. In 2000, the USDHHS went on to advocate increasing the proportion of Americans who engage in regular, moderate physical activity and decreasing the proportion of Americans who lead a sedentary lifestyle. It is important to note that the built environment can be modified to facilitate or constrain physical activity. Specifically, it can be structured in ways that increase opportunities for and reduce barriers to physical activity. 
At a time where more urban dwellers are also expressing feelings of loneliness, it is becoming increasingly important to consider the role built form can play in strengthening social bonds. Dense social networks in a neighbourhood, through a community event or organization for example, can foster stronger community ties and engagement and improve perceived safety. Social capital forms the networks and norms of reciprocity and trust, and emerging evidence indicates that social connections are among the most robust correlates of subjective wellbeing (Helliwell and Putnam 2004). People with strong social networks are less likely to experience sadness, loneliness, low self-esteem, and problems with eating and sleeping. Research on the correlates of life satisfaction have found that subjective wellbeing is best predicted by the breath and depth of one's social connections, and that people themselves report that good relationships are prerequisites for their happiness far more than money or fame (Helliwell and Putnam 2004).

The Commission for Architecture and the Built Environment (2009), a public body tasked with advising the UK government on architecture, urban design, and public space in England, examined how the quality of social infrastructure directly affects residents. They found that by providing safe spaces for communities to meet with one another and sustainable transport networks, urban design can support and promote strong community engagement. In particular, children's happiness, health, development, and life chances are significantly affected by the quality of local social infrastructure (Adams 2014).

In his book Happy City (2013), author Charles Montgomery affirms that cities around the world suffer from a social deficit. He references a study conducted in 2008 by a team of Italian economists that tried to account for a seemingly inexplicable gap between rising income and flatlining happiness in the United States. After removing various components of economic and 
social data from their models, the researchers found that the only factor powerful enough to hold down people's self-reported happiness in the face of rising wealth was the country's declining social capital. In the year 2000, Robert Putnam warned that networks of lighter social relationships had been dwindling for decades, and Montgomery argues that this trend continues to this day. "In 1985 the typical American reported having three people [they] could confide in about important matters. By 2004 [their] network had shrunk to two, and it hasn't bounced back since" (Montgomery 2013:54). While Montgomery speaks more to social capital in a suburban context, he still draws an essential connection between the fabric of urban form and social capital.

Smith et al. (1997) analyzed matrices of physical form criteria and their effects on community quality and deduced that the 10 design criteria that have the strongest relationship to community quality are: (1) walkable community, (2) outdoor amenities, (3) plentiful seating, (4) barrier free, (5) open space areas in residential areas, (6) well maintained (7) active sports facilities, (8) landscaping elements, (9) preservation of natural and cultural features, and (10) variety of behaviour settings. These are all important urban design factors to consider in creating an urban fabric more conducive to improved wellbeing. In order to analyze how social capital can be harnessed and enhanced in an urban environment, its relationship to greenery, walkability, and density must be explored.

With the major stresses to urban wellbeing outlined, this MRP now turns to a deeper examination of urban design's role in mitigating these issues. They shall be addressed through the built environment features of urban greenery, walkability, and density, and sub-categorized through the mental, physical, and social dimensions of health. There are many different types of 
spaces and built environment features that each nurture a sense of wellbeing, but it is important to focus on elements of the built environment over which planning and urban design professionals have most influence. The first element this MRP will investigate is the presence of green, natural settings.

\section{Urban Greenery}

Urban greenery has been demonstrably effective at alleviating the mental and physical stresses urban residents face. In the 19th century, Frederick Law Olmsted observed that simply viewing nature reduces the stress of daily urban life (Olmsted 1865). Parks and gardens have long been noted for their restorative effects on overall health, and while the reasons behind this phenomenon remain mystifying, 34 of the 37 studies the City of Toronto reviewed when researching why nature matters to health found statistically significant associations between green space and reported mental health (City of Toronto 2015).

\section{$\underline{\text { Mental Health }}$}

It is well supported that the benefits of natural, green, and open spaces extend beyond the provision of trails for walking and fields for playing. Wilson and Kelling (1984) popularized the biophilia hypothesis that suggests humans share an instinctive bond with other living systems; the removal of these natural elements, including plants, animals, and even the weather, via much of urban development is fundamentally detrimental to health. Innumerable studies about the relationship between nature and health have since been undertaken, and while many have demonstrable effects, many also fail to concretely explain just why exposure to natural elements 
affects us so strongly. Grinde and Patil (2009), for example, examined the health benefits of simply looking at nature and concluded that an environment devoid of nature has a measurable negative effect on the perception of health and quality of life. In Adelaide, Australia, Sugiyama and Ward Thompson (2008) explored the link between mental and physical health and perceived greenness in the environment. Their findings assert that a significant relationship exists between greenness and mental health, although recreational walking and social coherence only accounted for part of this association. They hypothesize that it is more broadly the restorative effects of natural environments that explains the connection. A significant literature review compiled by Abraham, Sommerhalder, and Abel (2010) summarized the health benefits of contact with nature as: the promotion of mental wellbeing through attention restoration; stress reduction; and social engagement and participation. This MRP will more specifically address the social aspects of built urban environments later, but it is worth mentioning here as it is one of the key ways urban greenery alleviates ill-being.

Small-scale encounters with nature are equally as significant to health as access to large areas of natural open space. Urban greenspace is increasingly important in alleviating the stresses often associated with higher density living, including noise and lack of privacy. Maller, Henderson-Wilson, and Townsend (2010) investigated links between inner city high-rise living, access to nature, and health in Sydney and Melbourne, Australia. Across thirty in-depth interviews, they found that most interviewees expressed an innate desire for some connection to natural elements. Interviewees preferred natural scenery that included trees, parks, or bodies of water, and expressed that simply having a view of natural elements induced feelings of relaxation. Gildöf-Gunnarsson and Öhrstrom (2007) echoed how easy access to nearby green 
areas was found to offer relief from long-term noise annoyances and reduce the prevalence of stress-related psychological symptoms. Guite, Clark, and Ackrill (2006) measured the impact of various physical built environment factors on mental health for urban residents in London's highdensity areas; they found that the perceived ability to escape to greenspaces away from noise and over-crowding was significantly linked to mental wellbeing.

Bearing this instinctive biophilic relationship humans share with other living systems, it is essential that urban environments are planned and managed in ways that support this bond. If decision makers are increasingly recognizing the importance of improving population health and wellbeing, data clearly shows aggregate gains from increasing the amount of green space in urban settings. As White et al. (2013:927) aptly write, "[even] small benefits to individuals can have large impacts if, like green space, they touch many people." This is patently true when one considers the work of Mitchell and Popham (2008) that attests that additional greenspace may be especially beneficial for the poorest urban dwellers, and as such, may help address social inequalities in health and wellbeing.

\section{$\underline{\text { Physical Health }}$}

Proximity and accessibility is a critical first step in incorporating the wellbeing benefits of greenspace. Greenery does not have to be reserved for dedicated spaces like parkettes and reserves, but can be experienced and appreciated just by walking down the street. A recent study of green space in Toronto looked at the presence of street trees in relation to personal health. It found that urban dwellers that live in areas with higher street tree density report better health and 
fewer cardio-metabolic conditions when compared to those living in areas with lower street tree density (City of Toronto 2015).

The study further estimated that planting 10 more trees on a city block would improve health perception and decrease cardio-metabolic conditions to the same extent as increasing the income of each household on that block by about $\$ 10,000$ per year. This increased sense of wellbeing would also be equivalent to feeling seven years younger on average (Ibid, 5).

Overall, available evidence also suggests that access to and use of greenspace is associated with increased physical activity and lower rates of obesity. The City of Toronto's (2015) review also found that children with a playground located within one kilometre of their living environment were almost five times more likely to have a healthy weight than a child without a nearby playground, even after correcting for income. The health benefits of greenspace are more strongly associated with greenspace that is within one kilometre from an urban dweller's place of residence. "Health gains have been documented with modest increases in nearby greenspace because people generally do not compensate for a lack of nearby greenspace by visiting public parks or green spaces that are farther away" (Ibid, 9). Physical activity done in a greenspace has also been found to be more beneficial to health than physical activity conducted indoors; researchers muse that this is largely in part to the enhanced sense of enjoyment catalyzed by being outdoors, along with the other positive psychological factors that accompany time spent amongst greenery (Ibid). Greenspace also has the capacity to improve neighbourhood health by mediating harmful physical interpersonal factors. For example, a study in Chicago found that public housing residents living in a building surrounded by trees and grass reported less aggression and violence than residents living in relatively barren buildings (Ibid). This, in turn, 
improves the real and perceived sense of safety and helps hone a neighbourhood environment that can more readily catalyze physical engagement and activity. Above all, a greenspace must be perceived as safe and well maintained to provide health benefits. One particular greenspace typology is effective at bringing all of the aforementioned health benefits and sense of belonging together: community gardens. "People who participate in community gardening report increased physical activity, improved mental health, and enhanced social health and community cohesion" (Ibid, 6). While not feasible everywhere, community gardens are a uniquely important neighbourhood urban design consideration.

\section{$\underline{\text { Social Capital }}$}

A healthy built environment is one that connects citizens together to create a sense of community. Formal public places like town squares, plazas, parks, and gardens cultivate community in numerous ways, but equally significant are the interstitial and informal places, such as those in between buildings, on the street, or at the train station or bus stop. Professors Susan Thompson and Jennifer Kent from the Faculty of built Environment at the University of New South Wales maintain that the careful design of open space can encourage human interaction as part of community creation (2014). They argue that removing the intrinsic biophilic bond shared between humans and other living systems by 'building out' natural elements is fundamentally detrimental to health (Thompson and Kent 2014). In the Netherlands, Maas et al. (2009) explored the idea that greenspace improves wellbeing simply due to the ways it can foster increased social contact. Their study found an inverse relationship between greenspace in people's living environment and feelings of loneliness. They also deduced that less 
greenspace is associated with a perceived shortage of social support amongst urban dwellers in their local neighbourhood. Cohen, Inagami, and Finch (2008) cross-referenced data from the Los Angeles Family and Neighbourhood Study with geographical information and discovered that parks commonly act as the primary place for neighbourhood social interactions. Sugiyama and Ward Thompson (2007) echoed this sentiment in their work, having found that parks were integral to interaction in an elderly cohort of UK residents. Thompson and Kent (2014) also reference the importance of community gardens and farms as forums for incidental and organized social interaction in the ways they allow people to establish and maintain contact with community and nature. During the community garden movement in the UK, Holland (2004:1) concluded that while some gardens played a strategic role in good production, all were "based in a sense of community, with participation and involvement being particularly strong features." In Toronto, Wakefield et al. (2007) also researched the wellbeing impact of community gardens and concluded that they successfully contribute to better physical and psychological health, the latter of which is attributed to contact with nature and the general sense of community that occurs from people gardening together. In an examination of community gardens in an Australian context, community gardeners described their plots as places of refuge and social support, where advice and knowledge is shared (Kingsly, Townsend, and Henderson-Wilson 2009). However, in order to be effective as possible, community gardens must be situated within a patchwork of streets that in themselves provide the scaffolding for community connectivity (Thompson and Kent 2014).

When constructing greenspace, urban designers must not only weigh typological and aesthetic considerations, but they must also be wary of the different experiences and 
programmatic needs desired by different age groups. In her 2002 book Growing up in an Urbanising World, American planning and architecture professor Louise Chawla observed that the neighbourhood features teenagers valued in the 1990s were remarkably consistent with the features desired in the 1970s. Then, adolescents reported using overgrown vacant land for exploring, creative play, and hideaways, and used parks for socializing, active play, and appreciating trees and gardens. More recently, adolescents defined environments that support good health as 'being outside' in a safe, clean, green, and liveable space (Woodgate and Skarlato 2015). Time and time again, adolescents continue to highly prize active and accessible greenspace. Adults have similarly expressed a sensory-dominant experience of greenspace, but their perception of natural environments and human health is rooted more in 'serene' green space, followed by increased 'space', 'nature', 'species richness', 'refuge', 'culture', 'prospect', and 'social' dimensions (Grahn and Stigsdotter 2010). The dimensions of 'refuge' and 'nature' were most strongly correlated with stress, and from a design perspective, Grahn and Stigsdotter's (2010) study suggests that a combination of refuge and nature could be interpreted as the most restorative environment for stressed individuals.

British human geographer and researcher Mags Adams (2014) believes that by examining the sensory experiences of urban spaces it is possible to identify two realms in which quality of life is affected: the physical realm, and the emotional realm. Whereas the physical realm deals with the tangible, corporeal, material aspects of the built environment, the emotional realm deals with the more ethereal aspects of urban spaces that impact the physical realm. The emotional realm "deals with people and their relationships to each other, their rapport with places, their senses of community, and the differences experienced by different people at different 
times" (Adams 2014:6). The physical and emotional are intertwined, and urban design must negotiate this interconnection to create urban spaces that contribute to a positive quality of life and wellbeing. In order to create the 'right' sensory experience, consideration must be given to the interpretation of individual and emotive responses to sensory stimuli. It is the activities of people that matter most, and there are ways to physically enhance spaces to allow for desired sensory experience.

\section{Walkability}

While greenspaces and their experiences are notable as a point of study on their own, the urban physical environment encompasses a wide range of built features that all come together to form one broader experience. However, in the scope of health as it relates to wellbeing, there is one particular marker of a successful, healthy built form. As the classification suggests, 'walkable' communities feature a number of characteristics that encourage tacit physical activity in the form of walking. Walking is proven as a healthy and inexpensive way to enhance individuals' health, but only certain attributes are related to increased walking by community members, including smaller block size, generous and well-maintained sidewalks, and a short distance to groceries and retail amenities (Kwon et al. 2017).

\section{Physical Health}

The Surgeon General at the U.S. Department of Health and Human Services conducted an exhaustive review in 1996 and concluded that substantial health gains could be realized if all persons included regular, moderate physical activity in their lives (Frank and Engelke 2001). 
Statistics Canada carried out the Canadian Health Measures Survey to ask participants how much daily physical activity they get, and based on data collected in 2015 and 2016, found that the measured amount of physical activity was far less than participants' own descriptions; “on average, they claimed to get 49 minutes of activity per day, while the devices [issued to monitor activity] found they got 23 minutes" (Abedi 2018:1). In analyzing the American 1995 Nationwide Personal Transportation Survey data, Ross and Dunning (1997) found that approximately $83 \%$ of all 'trips' (each instance of moving from a point of origin to a destination) in a city are short, for non-work purposes, and occur relatively close to home. Because most nonwork trips are within walking or cycling distance, creating streets that are attractive and conducive to safe active transport can strengthen connectivity, encourage higher levels of physical activity, and improve wellbeing.

Urban design and transportation planning research has long understood that neighbourhood design and land use affects transportation choice in an urban context (Frank 2000). The appearance and attractiveness of a neighbourhood is also integral to a walkable community, as an American national survey found that 'physical beauty' was among the reasons that people choose to live in, stay in, and develop emotional ties to an area. Lovasi et al. (2013) found that attractive neighbourhoods were associated with a lower average Body Mass Index, which they attributed to increased physical activity via walking, but the relationship between walkability and health does not end there. Physical health and wellbeing have come to be associated with high levels of active recreation, and community attractiveness is also a strong predictor of recreational wellbeing, suggesting that neighbourhood upkeep is important in encouraging recreational activity (Kwon et al. 2017). 
As Frank and Engelke (2001) say, pedestrians and cyclists are more sensitive to the built environment's urban design features than the motorist. Amos Rapoport (1987) studied the culture and perception of pedestrian street use in New York and argued that the critical determinant of urban design features is the 'number of noticeable differences.' This is a function of the rate at which a person moves through the built environment. The speed of a motorist inhibits their ability to process detail in the environment, and as such, the ideal environment for a motorist is low in complexity. Conversely, pedestrian and bicycle travel is far slower and affords the ability to notice differences in the streetscape. Rapoport (1987) states that a rich pedestrian environment, therefore, is one that maintains a pedestrian's visual and sensory attention. Specifically, streets that are abrupt, irregular, complex, and changing are more highly valued by a pedestrian. Streets with generous sidewalks, bicycle infrastructure, and crosswalks designed for pedestrian priority will be perceived as safer. Heath et al. (2012) have also concluded that the physical environment is an important consideration in encouraging recreation participation. After deducing that physical factors can influence recreational wellbeing, Kwon et al.'s (2017) research went on to find that recreational quality of life was closely related to physical health and wellbeing. Work from Bauman et al. (2012) also supports that those that engage in higher levels of recreational and leisure activities reported better physical wellbeing. Kwon et al. (2017) went on the hypothesize that physical wellbeing was positively related to happiness and general life satisfaction, and their work also proved this relationship to be statistically significant.

But again, a public realm with effective design is the core of facilitating increased recreation and physical activity, especially through walking. The crucible of this relationship rests with the pedestrian pathway. "Survey results indicate that the presence of sidewalks, busy 
streets, enjoyable scenery, and hills promote walking for exercise.... [Pedestrian] paths separated from the street and human activity are not used, but those adjacent to streets and winding through mixed land uses and small lot sizes are" (Jackson 2003:195). Poor lighting, excessive noise, heavy traffic, and lack of public transit are also associated with reduced physical activity and, most specifically, the loss of physical function in adults over 55 years of age (Ibid). Previous literature suggests that these detrimental environmental features discourage neighbourhood excursions. The presence of public buildings and other landmarks embedded in a logical pattern are also elements of neighbourhood design that share a direct correlation to human health and wellbeing. Psychologically, visual landmarks and logical transit pathways provide a sense of ease and comfort because they assist people in reaching their destinations (Ibid). These public realm elements play a part in human-scale neighbourhood design, and their presence are important ingredients in a sense of security and belonging.

\section{$\underline{\text { Social Capital }}$}

When someone says that a place is very walkable, they are referring to a general sense of liveliness, vitality, sociability, or vibrancy. In his seminal book Walkable Cities, Jeff Speck (2012) explains that walkability is equally a means and a measure. He explains that while the physical and social rewards of walking are many, "walkability is perhaps most useful as it contributes to urban vitality and most meaningful as an indicator of that vitality... Get walkability right and so much of the rest [in terms of making cities more livable and successful] will follow" (Speck 2012:x). While it is largely agreed upon that a walkable urban fabric is a desirable fabric, it is still a concept that relies on several intertwining components. Ann Forsyth 
(2015:276) conducted a literature review and grouped the key themes or dimensions of walkability, creating clusters of definitions related to some of the means for creating walkability:

- Traversable environments have the basic physical conditions to allow people to get from one place to another without major impediments, for example, relatively smooth paths.

- Compact places provide short distances to destinations for those who are walking for utility.

- Several different dimensions are key to places being safe for walking - perceived and actual crime and perceived and actual traffic safety. Both are about potential harm to the person.

- Physically enticing environments have full pedestrian facilities such as sidewalks or paths, marked pedestrian crossings, appropriate lighting and street furniture, useful signage, and street trees. They may also include interesting architecture, pleasant views and abundant services attractive to those who have other choices for getting around and getting exercise. ...

- [Walkability] is in many cases a way of talking about environments that are simply better - with walkability representing a holistic solution to improving urban areas - slower paced, more human scaled, healthier, and happier.

Kevin Leyden (2003) sought to examine whether the built environment affected the degree to which people are involved in their communities and with one another. "The fundamental premise is that some neighbourhood designs enable or encourage social ties or community connections, whereas others do not" (Leyden 2003:1546). He conducted a survey in and around the city of Galway, Ireland; as one of the fastest-growing cities in Europe, it was chosen because of its range of housing types, from the mixed-use and pedestrian-oriented variety to the contemporary, American-style suburb. The survey evaluated how easily different communities could walk to certain key neighbourhood buildings, like a local corner shop or park. The results indicate that residents living in walkable neighbourhoods are more likely to know their neighbours, to trust others, and to be involved socially. Leyden (2003) confirmed that the 
'traditional' neighbourhood design typology was the most likely to promote social capital. Compared to cul-de-sac designs, traditional neighbourhood design's consolidated grid-like streets and access to shopping and pedestrian environments exhibit increased casual social interaction. There is also research suggesting that streets designed for walking and cycling also promote social interaction; "this relates to the fact that both utilitarian and recreational walking and cycling increase the chance of incidental social interaction" (Thompson and Kent 2014). In Montreal, Canada, Richard et al. (2009) found regular walking to be a strong predictor of social participation by the elderly. Mehta (2007) observed the environmental qualities of commercial streets in the Boston metropolitan area and their influence on social interaction. Mehta concluded that, rather than simply channels of movement, commercial streets were in demand as social places for strolling and meeting. It was found that a physically well-designed pedestrian-oriented street with generous sidewalks, street furniture, green landscaping, and articulated street facades becomes more meaningful for people when there are community gathering places and other supporting land uses at the street level (Mehta 2007). Streets ultimately provide the backdrop for interaction, but there are environmental factors that play an important role in supporting or discouraging walking. Certainly, walking behaviour takes place on city blocks that offer limited usefulness, comfort, sources of sensory pleasure, and places to commune. "But there, people most likely walked as a necessary activity - going to work or another destination - and not as an optional or social activity" (Mehta 2008:240).

It is clear that walkability has urban design elements that tangibly affect the physical and social activity amongst urban dwellers. As a means to better physical health and a more enjoyable experience of the public realm, walkability possesses immense strength. However, it 
would be remiss to not discuss another particular element of urban built form that holds a symbiotic relationship with walkability.

\section{Density}

Kent and Thompson (2014) argue that accessibility is the primary link to improving the relationship between health and the built environment. Distance is significantly correlated with the use of active transport in the majority of the literature, with proximity and walkable distance strongly associated with both utilitarian and recreational walking and cycling (Kent and Thompson 2014). However, this relationship is not linear, and one of the most complex factors at play is the link to residential population density. Higher residential densities lead to shorter distances between origins and destinations, suggesting that in denser urban areas, distances between locations are shorter and can more easily be bridged on foot or by bicycle. As the US Transportation Research Board (2005) established, residential density alone cannot promote more active transport; it must be done in tandem with mixing and connecting land uses to bring services and other destinations closer to where people live and work.

\section{Mental Health}

A tight, walkable street grid is typically matched with higher concentrations of built density when compared to a more sprawling street fabric. Density is inseparable from cities, and it is how a city achieves its concentration of employment, services, and creativity (Ellard 2012). However, the inherent fast-pace and crowding of dense built environments create a psychological overload by intensifying stimuli for urban dwellers. In serious instances, this can manifest itself 
amongst a city resident as occasioning detachment and a retreat to social isolation (OkuliczKozaryn and Mazelis 2018). Cities generate tension and conflict, and high density was found to predict low happiness (Okulicz-Kozaryn and Mazelis 2018). Recent neurological evidence confirms that great cities overstimulate our brains to an unhealthy point, and the abundance of choice exemplified in cities can lead to depression, loneliness, anxiety, and stress (Smith 2018, Park 2011). As documented in earlier studies, Americans do not merely prefer smaller areas, but they are also happier in smaller areas (Fuggit and Brown 1990). In their research, OkuliczKozaryn and Mazelis (2018) found that people living outside of metropolitan areas as compared with central cities are happier by 0.05 on a scale from 1 to 4 . This difference may appear to be small, but it is still important in practical terms as an ecological difference of 0.05 on a happiness scale from 1 to 4 can translate to large effects. "[For] example, all else being equal, if one-third of $1 \%$ of the US population, about 1 million people, who live in central cities instead lived in non-urban areas, it would mean about 50,000 people would be satisfied with their lives rather than dissatisfied" (Okulicz-Kozaryn and Mazelis 2018:355). The study reinforces that happiness is largely due to person-level influences like employment, and ecology is secondary, but it also presents a paradox. Milton Glaeser (2011) notably claimed that people are happier in cities, and more recent studies have also spoken to how dense built form can foster improved wellbeing for urban residents.

Kyttä et al. (2016) conducted a context-sensitive study of the social sustainability of urban settings. Here, they frame social sustainability as consisting of two main dimensions: accessibility (of services and opportunities) and experiential outcomes (pride in neighbourhood, social interaction, perceived safety and quality of the environment). Their results indicate that 
densely built urban neighbourhoods can include characteristics that support social sustainability. The research team found that "residents living in the Helsinki metropolitan area in Finland generally evaluated the quality of their environment higher in urban than suburban neighbourhoods in terms of appearance, atmosphere, and social and functional quality" (Kyttä et al. 2016:51). They attribute this finding at least partly to the strong functionalists tradition of Finnish architecture and planning. The research team also uncovered significantly differing patterns of social sustainability across urban and suburban settings. Urban density promoted easy access to everyday services in both urban and suburban contexts, but the experiential outcomes varied. "In the urban context, easy access to services contributed to higher perceived environmental quality, whereas in the suburban settings, the closeness of services as well as the increasing density decreased perceived environmental quality" (Ibid). Closeness to services was also associated with wellbeing, albeit to opposite effects. In the urban context, closeness to services had positive outcomes, whereas closeness to services in the suburban context had negative outcomes. Having daily services close and easily accessible for errands was also shown to induce positive physical outcomes by promoting active transportation.

More recent work by Mouratidis (2018) has helped provide insight into the causal mechanisms between city-living and neighbourhood satisfaction. Through qualitative interviews, they found that compactness may have a positive influence on neighbourhood satisfaction and hence on livability, since neighbourhood satisfaction is used as a measure of livability. Compactcity interviewees highlighted the importance of accessibility, offering the follow testimonies:

- "The most important thing is the short distances to everything."

- "It makes it easier to relations and stuff. More urban ... ." 
- "If I lived outside of Oslo, I would have to spend so much time travelling by train or by car. And then wouldn't have time that I want to spend with my child and my husband."

- "The most important is that I have easy access to things ... . I think it will be easier [when I move to a compact urban area] to get to meet friends for [a cup of coffee] or something. You just don't have to plan it a week ahead" (Mouratidis 2018:2420).

The work of Mouratidis (2018) supports previous literature on the positive effect of high accessibility on livability. While the paradoxical effects of density on urban residents' mental health remains, Mouratidis' work also demonstrates that, with the appropriate design and infrastructural elements, density can truly be an asset to urban wellbeing.

\section{$\underline{\text { Social Capital }}$}

A consistently active sidewalk life and the interactions that occur in local neighbourhood shops, for example, make other community members less anonymous, leading people to take more responsibility over the wellbeing of others and the city itself (Mouratidis 2018). The consistent face-to-face contacts that occur in dense, urban neighbourhoods encourage a sense of public trust and social connectedness among city inhabitants. The compactness of urban form is found to have a statistically significant direct positive effect on opportunities to meet new people, the number of close relationships, and frequency of socializing (Ibid). Research suggests that residents of compact neighbourhoods are, in general, "more satisfied with their personal relationships as they have larger networks of close relationships, meet friends and relatives more regularly, receive stronger social support, and have more opportunities to meet new people compared with residents of low-density suburban neighbourhoods" (Ibid, 11). 
Density has significant positive total effects on opportunities to meet new people and frequency of socializing, and one's distance to the city centre has the strongest and most significant total effect on personal relationships satisfaction. According to the author, "[residents] living closer to the city centre are found to be significantly more satisfied with their personal relationships and to have larger networks of close relationships, meet friends and relatives more regularly, and receive stronger social support" (Ibid). Interview data suggests three factors attributed to compact city structure and social capital: (1) more people within close proximity due to high density and centrality, (2) higher access to third places, and (3) higher access to and from other areas due to centrality and public transport (Ibid). At the micro-level of a student dormitory, Festinger, Schacter, and Back (1950) first concluded that having more people within close proximity makes socializing more accessible. Mouratidis (2018) argues that this effect extends to the macro-level of the city region, and is qualitatively implied through the interviewee testimony they have gathered in their research. One compact area resident, aged 32, said: ... socially it's very good. With all the cafes and restaurants and the parks that are around here. It's easy to find something to do. And also, most of the times if we have friends visiting or we are going out to meet friends, we end up here. Because this is where everything is happening more or less (Ibid, 14).

The core explanation of why social life is facilitated in compact neighbourhoods is higher access to and from other areas. Shorter travel distances due to centrality, and higher accessibility through public transit and pedestrian infrastructure, make it easier for residents of dense urban environments to socialize.

The testimony also suggests that to facilitate social life, both a high concentration of people and third places for them together are necessary. Oldenburg (1989) defines third places as 
the interstitial public places that host the regular, voluntary, and informal gatherings of individuals beyond the realm of home and work. They can be public places, like a playground or public bench, or private places, like a pub or cafe. They can be large spaces, like a town square of train station, or smaller ones, like a stairwell or stoop. They are "distinguished from other areas where social interaction might occur in that there is no sense of having to perform a 'role' third places are, therefore, not specifically at 'home', 'work' or 'school'” (Thompson and Kent 2014:265). Leyden et al. (2011) goes to the length of expressing that third places are prerequisites for cities and city neighbourhoods because they promote social connections and personal wellbeing. Williams and Pocock (2010) argue that third places encourage connected networks of community, and that the more opportunities that exist for communities to connect, the greater the chance of developing tangible, lasting, and caring connections. Third places influence social life and personal relationships by motivating people to meet socially or participate in leisure activities together and they also increase the chance of spontaneously meeting preexisting or new acquaintances.

From an urban design perspective, Mehta (2009) found that sidewalk width and permeability of creating a streetscape environment that is conducive to the creation of incidental social interaction and third places. Sidewalks provide a stage to house artifacts and features to support social activities; a certain minimum width of sidewalk is required to accommodate the activities at the edges of buildings, the pedestrian flow of traffic, and space for street furniture and landscaping. Sidewalk width is obviously necessary to accommodate pedestrian traffic, but it is even more critical to have a wider sidewalk area to support the stationary activities involved in a social public realm. According to the author, sidewalk width is critical because it is a 
prerequisite for supporting other street characteristics, such as space for display of wares and signs, trees, and street furniture that were crucial to support social activities (Mehta 2009). The most socially lively areas have a high permeability to their streetscape. People will not linger or engage in social activities where there is nothing to do or see in their surroundings, but in the most permeable areas, people who were recreationally passing through were generally curious about what went on in the buildings and spaces along their path. In contrast, 'dead spaces', which are blank building surfaces that one cannot see through at the street level, have no opportunity to engage and subsequently repel passersby. The study by Mehta showed that the permeability in the liveliest settings was not solely limited to visual stimuli, but was also enhanced by storefronts that left their doors and windows open, letting the people outside sensorily engage with the activities inside and vice versa (Ibid).

It is true that some of Mehta's strongest observations and recommendations are based on the actions of urban residents themselves, but the literature more broadly demonstrates that urban planning and design both matter to quality of life as the structure of built form affects personal relationships. Practitioners and decision makers thus have the means to positively influence people's lives through careful urban design and supporting uses. At a time where the threat of loneliness is becoming evermore pertinent, understanding how dense urban environments, when designed appropriately, can be beneficial for existing and new relationships alike is essential in harnessing the strong personal influence personal relationships have on wellbeing. 


\section{Summary}

This literature review provided a substantial amount of information pertaining to urban built form principles and design interventions for improved wellbeing. Before moving on, this section's major urban design takeaways should be summarized:

1. Urban greenery improves wellbeing by providing restorative landscaping and spaces to congregate, socialize, and recreate.

2. Walkability improves wellbeing by championing compact, traversable design that encourages simple, regular physical activity. A walkable public realm also offers greater potential for increased incidental, informal social opportunities.

3. Density improves wellbeing by enhancing accessibility to local goods, services, and social opportunities. A dense built form can also host a greater number of third places for urban residents to congregate at.

The following points are the urban design considerations most strongly linked to influencing wellbeing in an urban context across their respective design concepts:

\section{Greenery}

- Small-scale encounters with nature are equally as significant to health as access to large areas of natural open space. Greenery does not need to be reserved for parks, but can be experienced and appreciated just by walking down the street (Maller, Henderson-Wilson, and Townsend 2010).

- Accessibility to urban greenery is fundamentally critical. Greenspace within one kilometre of an urban dweller's place of residence produces the greatest health benefits (City of Toronto 2015).

- Urban residents tend to prefer natural scenery, including trees, parks, or bodies of water; simply having a view of these elements induces feelings of relaxation. A combination of refuge and nature is typically interpreted as the most restorative environment for stressed individuals (Maller, Henderson-Wilson, and Townsend 2010). 
- Greenspace must be perceived as safe and well maintained to provide health benefits. Increased local greenspace is associated with stronger social support amongst urban dwellers (City of Toronto 2015).

- Community gardens contribute to better physical and psychological health. Community gardeners described their plots as places of refuge and social support (Kingsly, Townsend, and Henderson-Wilson 2009).

\section{Walkability}

- Community attractiveness is a strong predictor of recreational wellbeing, suggesting that neighbourhood upkeep is important in encouraging recreational activity (Kwon et al. 2017).

- The presence of sidewalks, busy streets, enjoyable scenery, and hills promote walking for exercise (Jackson 2003).

- Walkable environments are compact, easily traversable, safe, and offer physically enticing pedestrian facilities like paths and crossings, lighting and street furniture, landscaping, interesting architecture, views, and abundant services (Forsyth 2015).

- A physically well-designed pedestrian-oriented street becomes more meaningful for people when there are community gathering places and other supporting land uses at the street level (Mehta 2007).

- The 'traditional' neighbourhood design typology is the most likely to promote social capital. Streets designed for walking and cycling also promote social interaction (Leyden 2003).

\section{Density}

- Neighbourhood compactness positively influences urban wellbeing through increased access to goods, services, and recreation. It also positively affects opportunities to meet new people, the number of close relationships one has, and frequency of socializing (Mouratidis 2018).

- Social life is more easily facilitated in denser environments because of increased accessibility due to centrality, transit options, and pedestrian infrastructure. A higher concentration of people also requires a higher concentration of third places to facilitate social life (Ibid).

- Sidewalk width and at-grade streetscape permeability create a public environment that is conducive to the creation of incidental social interaction and third spaces. Wider sidewalk width is especially important because it supports the stationary activities involved in a social public realm (Mehta 2009).

- Density has a paradoxical effect on the mental health of urban residents, but its capacity to positively influence urban wellbeing can be emphasized through appropriate design and infrastructural elements (Okulicz-Kozaryn and Mazelis 2018, Mouratidis 2018). 


\section{CHAPTER THREE: Content Analysis}

The literature review reinforced that much of the existing work regarding the improvement of urban wellbeing centres around the dimensions of mental health, physical health, and social capital. The literature also consistently referenced the features of urban greenery, walkability, and density as having strong influences on urban wellbeing. The dimensions and features are each significant enough to warrant individual examination, but more importantly, they play mutually reinforcing roles in the broader pursuit of urban wellbeing. Ultimately, each concept has potential design interventions that can create a public realm more conducive to wellbeing.

\section{Secondary Plan Content Analysis Methodology}

This section of the MRP seeks to ground the discussions introduced in previous sections, exploring how the City of Toronto engages (or not) with the relationship between urban design and urban wellbeing in its planning documents. In order to do so, I will compare two Secondary Plans from two different neighbourhood typologies in Toronto. Using data sourced from Wellbeing Toronto², I will select one Secondary Plan for a suburban, low-income neighbourhood and one Secondary Plan for an urban, high-income neighbourhood. I have chosen to examine the York University Secondary Plan for a suburban, low-income context, and the Yonge-Eglinton

\footnotetext{
2 Wellbeing Toronto is a mapping application developed by the City of Toronto's Social Research Department that allows the user to select a number of datasets at the neighbourhood level and have the results presented as a map, tables, and graphs. Wellbeing Toronto uses census demographic data in order to support neighbourhood level planning. For the purpose of this content analysis, Wellbeing Toronto's data helps establish a very simple framework for comparing the neighbourhood profiles. The data I use includes: (1) area, (2) population, (3) average family income, (4) Walk Score, and (5) visible minority population.
} 
Secondary Plan for an urban, high-income context. This exercise will examine how the Secondary Plans address the built environment features of urban greenery, walkability, and density, and whether such concepts are mentioned in reference to the dimensions of mental health, physical health, and social capital or not. It may also highlight if and how references to greenery, walkability, and density vary between neighbourhoods, suggesting an unequal emphasis on the way the City approaches urban design infrastructure in both communities. By choosing two neighbourhoods that are very different from one another, any differences should be more pronounced and easily observable; this will help craft a clearer assessment of the relationship between urban design and urban wellbeing in the chosen Secondary Plans. This follows the methodological principles of maximum variation case studies and will help showcase the significance of any differing variables (Flyvbjerg 2011). The examination of Secondary Plans is particularly useful because they are enforceable planning sub-documents for the City of Toronto. Given Ontario's policy-driven land use planning system, the Official Plan is the key legally binding document regulating planning in the City of Toronto. It has numerous provisions that regulate decisions regarding the built environment in areas such as land use development, hard services, and environmental protection. Secondary Plans are more detailed local development policies to guide growth and change in a defined area of the City. As such, they can provide more detailed insight into the creation of new neighbourhoods and employment districts and help implement the objectives, policies, land use designations and overall planning approach of the Official Plan to fit local contexts.

Wellbeing Toronto's online map provides data on a neighbourhood-to-neighbourhood basis - that is, it defines its data's geographic boundaries according to the City of Toronto's 140 
neighbourhood profiles. ${ }^{3}$ As a result, population data can only be viewed at the neighbourhood profile level. Contrarily, the City of Toronto's Secondary Plans operate on different geographic boundaries that are specific to the Secondary Plans themselves. This means that the Secondary Plan study areas do not necessarily coincide geographically with the neighbourhood boundaries outlined on Wellbeing Toronto's map. The York University and Yonge-Eglinton Secondary Plans were first selected as candidates for this exercise because I was most closely able to match their geographic boundaries with the City's neighbourhood profiles. On Wellbeing Toronto, neighbourhood profiles are identified by an ID number. The York University Secondary Plan is matched very closely to York University Heights (ID \#27), and the Yonge-Eglinton Secondary Plan is matched most closely with a combination of Yonge-Eglinton (ID \#100), Mount Pleasant West (ID \#104), and Mount Pleasant East (ID \#99). From hereon, any reference to the three neighbourhoods that make up the Yonge-Eglinton Secondary Plan's geographic boundary will be referred to as 'sub-neighbourhoods', and any reference to 'Yonge-Eglinton' will refer to the area constructed by these three neighbourhoods combined. For the context of this MRP, any mention of 'York University' will refer to the academic campus, and any mention of 'York University Heights' will refer to the neighbourhood including and surrounding York University's Keele Campus.

One can argue that a university neighbourhood has a particular nature that may lend itself to certain characteristics, such as a lower resident population or greater potential for public open

\footnotetext{
3 The Toronto neighbourhoods referenced on Wellbeing Toronto are defined according to Census Tract boundaries. For further information on Toronto's 140 neighbourhood profiles, please consult: https://www.toronto.ca/city-government/data-research-maps/neighbourhoodscommunities/neighbourhood-profiles/.
} 
spaces, compared to a mid-town neighbourhood like Yonge-Eglinton. However, given the contrasting demographic and socio-economic make-up of both neighbourhoods, and the possibility to accurately geographically cross-reference Wellbeing Toronto data with Secondary Plan policy, York University Heights serves as a relevant critical case to look at the relationship between urban design and urban wellbeing in the City of Toronto's Secondary Plans. The York University Secondary Plan also argues that, while it will permit sufficient flexibility for York University to meet its requirements, it will "still [provide] sufficient direction to meet city-wide planning objectives" (City of Toronto, 2015:7). Because this Plan keeps a focus on the City's broader planning goals, for the purpose of this MRP the York University Secondary Plan maintains relevance for comparison to Yonge-Eglinton.

The data compiled from Wellbeing Toronto offers a clear look at just how different the York University Heights and Yonge-Eglinton neighbourhoods are from one another. York University Heights carries an average family income of $\$ 59,616$, whereas residents of the YongeEglinton neighbourhood amass a cumulative average family income of $\$ 121,643$ when calculated as a weighted mean across the three sub-neighbourhoods' populations (City of Toronto 2019). The two chosen Secondary Plans and their respective neighbourhoods were also chosen because they significantly vary from one another in several substantial ways. Because much of this MRP deals with ideas of density and walkability, I also considered the neighbourhoods' populations, physical land area in square kilometres, and Walk Scores. York University Heights is home to 27,715 people over $13 \mathrm{~km}^{2}$ and has a Walk Score of 60 , whereas Yonge-Eglinton hosts 55,060 people in an area of $6 \mathrm{~km}^{2}$, boasting a cumulative Walk Score of 90 when calculated as a weighted mean across the three sub-neighbourhoods' land areas (City of Toronto 2019). As such, 
I make the distinction that York University Heights has a smaller population, families with typically lower annual incomes, a more sprawling physical footprint, and poorer walkability when compared to Yonge-Eglinton. Interestingly, $63.3 \%$ of York University Height's population are visible minorities, whereas only $21.0 \%$ of Yonge-Eglinton's population are visible minorities when calculated across its three sub-neighbourhoods. This might suggest that, because Toronto's urban neighbourhoods tend to be exclusionary by income bracket, many of the city's visible minority groups take residence in the suburbs and consequently live in places that are characterized by poorer urban design infrastructure, which as explained in previous sections can have a negative impact on a resident's urban wellbeing ${ }^{4}$. This idea is also substantiated through David Hulchanski's The Three Cities Within Toronto study (2007) that, through long-term trend analysis, revealed that visible minority groups persistently earn less income and become relegated to cheaper neighbourhoods situated at the city's periphery.

The following table shows the breakdown of neighbourhood-level data sourced from Wellbeing Toronto. The italicized cells show the data I used to calculate combined values for Yonge-Eglinton's sub-neighbourhoods.

4 The City of Toronto is aware of the varying access to city resources, services, and infrastructure across the 140 neighbourhoods, as suggested by the existence of the Toronto Strong Neighbourhood Strategy 2020 (TSNS2020) and the identification of Neighbourhood Improvement Areas. Unequal urban wellbeing is recognized by the City from a social planning perspective in the TSNS2020, but here, I am focusing on three urban design aspects specifically (greenery, walkability, density) as expressed in the binding planning documentation of the Official Plan and Secondary Plans. These documents are not highlighted in the TSNS2020 except for the Physical Surroundings domain. 
$\underline{\text { York University Heights and Yonge-Eglinton Profile Comparison }}{ }^{5}$

\begin{tabular}{|l|c|c|c|c|c|}
\hline & $\begin{array}{l}\text { York University } \\
\text { Heights (27)* }\end{array}$ & $\begin{array}{l}\text { Yonge-Eglinton } \\
(100)^{*}\end{array}$ & $\begin{array}{l}\text { Mount Pleasant } \\
\text { West (104)* }\end{array}$ & $\begin{array}{l}\text { Mount Pleasant } \\
\text { East (99)* }\end{array}$ & $\begin{array}{l}\text { Yonge-Eglinton (sub- } \\
\text { neighbourhoods } \\
\text { combined) }\end{array}$ \\
\hline Area & $13 \mathrm{~km}^{2}$ & $2 \mathrm{~km}^{2}$ & $1 \mathrm{~km}^{2}$ & $3 \mathrm{~km}^{2}$ & $6 \mathrm{~km}^{2}$ \\
\hline Population & 27,715 & 10,580 & 28,590 & 15,890 & 55,060 \\
\hline $\begin{array}{l}\text { Avg. Family } \\
\text { Income }\end{array}$ & $\$ 59,616$ & $\$ 172,275$ & $\$ 85,149$ & $\$ 153,593$ & $\$ 121,643$ \\
\hline Walk Score & 60 & 89 & 95 & 88 & 90 \\
\hline $\begin{array}{l}\text { Visible } \\
\text { Minority }\end{array}$ & $\begin{array}{c}63.3 \%(17,544 \\
\text { people) }\end{array}$ & $\begin{array}{c}15.0 \%(1,587 \\
\text { people) }\end{array}$ & $\begin{array}{c}28.2 \%(8,062 \\
\text { people) }\end{array}$ & $\begin{array}{c}12.2 \%(1,939 \\
\text { people })\end{array}$ & $21.0 \%(11,588$ people) \\
\hline
\end{tabular}

Source: Developed by the author. Data from Wellbeing Toronto neighbourhood profiles (City of Toronto 2019).

* The numbers in brackets are the neighbourhood numbers as used by the City of Toronto.

\section{Codes Guiding the Content Analysis}

Greenery, walkability, and density were each identified throughout the literature as urban design features that might have a significant influence on urban wellbeing. As such, I will analyze the content of the York University and Yonge-Eglinton Secondary Plans to assess if and how these urban design features are referred to in the context of each neighbourhood's design direction. In doing so, my goal is to see whether the Plans are consistent with the literature (i.e. that the Plans reference design elements and benefits referenced in this MRP) and how/if the Plans engrain and operationalize these design goals. The content analysis is guided by a keyword search that will allow to systematically and prescriptively categorize how the Secondary Plans

5 The neighbourhood profile of Yonge-Eglinton (100) represents 33.3\% of Yonge-Eglinton's total area and $19.215 \%$ of its total population. Mount Pleasant West (104) represents $16.7 \%$ of YongeEglinton's total area and $51.925 \%$ of its total population. Mount Pleasant East (99) represents $50 \%$ of Yonge-Eglinton's total area and $28.86 \%$ of its total population.

- Yonge-Eglinton's total average family income was calculated as a weighted mean across its sub-neighbourhoods' average family incomes.

- Yonge-Eglinton's total Walk Score was calculated as a weighted mean across its subneighbourhoods' areas. It was also rounded up from an original score of 89.5 to 90 because Wellbeing Toronto only presents Walk Scores as whole numbers. 
reference selected urban design elements and markers of health and wellbeing. This exercise utilizes selective coding (Mills, Durepos, and Wiebe 2010) to identify relevant built environment and health a priori themes that I will seek out in the Secondary Plans (see 'Coding Table'). Axial coding (Allen 2017) is then used to showcase relationships between the codes - for example, urban greenery and its relationship to mental health.

First, I will find how many times a particular keyword is mentioned within a Secondary Plan. I will then identify: in what context this keyword is used (in explicit reference to urban greenery, walkability, density, or in a different context); in what kind of statement (vision, policy, or tool for implementation); and whether it is mentioned in reference with mental health, physical health, or social capital. In doing so, this exercise will allow me to categorize the information and policy direction contained within each of the Secondary Plans to help illustrate how the City of Toronto is, or is not, addressing the link between urban design and urban wellbeing. The following table identifies and describes the rationale for each chosen keyword:

\section{Coding Table}

\begin{tabular}{|l|l|l|}
\hline \multicolumn{1}{|c|}{ Concept } & \multicolumn{1}{|c|}{ Keyword } & \multicolumn{1}{c|}{ Rationale } \\
\hline Greenery & Green & $\begin{array}{l}\text { This keyword will serve as a general catch-all for any broad references to } \\
\text { greenery (City of Toronto 2015). }\end{array}$ \\
\hline & Park & $\begin{array}{l}\text { Parks are typically an urban resident's most significant experience with } \\
\text { greenery, and they hold incredible weight regarding wellbeing (Abraham, } \\
\text { Sommerhalder, and Abel 2010). }\end{array}$ \\
\hline Tree & $\begin{array}{l}\text { Trees are often an urban resident's first point of contact with greenery on a } \\
\text { day-to-day basis, and they are consistently linked as having a significant } \\
\text { relationship with urban wellbeing (Maller, Henderson-Wilson, and } \\
\text { Townsend 2010). }\end{array}$ \\
\hline Walkability & Walk & $\begin{array}{l}\text { This keyword will serve as a general catch-all for any broad references to } \\
\text { walkability (Frank and Engelke 2001). }\end{array}$ \\
\hline
\end{tabular}




\begin{tabular}{|c|c|c|}
\hline Concept & Keyword & Rationale \\
\hline & Street & $\begin{array}{l}\text { Streets are the stage for public life, and their design holds a strong } \\
\text { influence on how inclined people are to use active transport (Mehta 2008). }\end{array}$ \\
\hline & Distance & $\begin{array}{l}\text { Distance is a strong predictor of walkability; the shorter the distance an } \\
\text { urban resident has to services and amenities, the more they will be inclined } \\
\text { to use active transport in their day-to-day lives (Kwon et al. 2017). }\end{array}$ \\
\hline \multirow[t]{2}{*}{ Density } & Density & $\begin{array}{l}\text { This keyword will serve as a general catch-all for any broad references to } \\
\text { density (Kyttä et al. 2016). }\end{array}$ \\
\hline & Height & Building height is a symbiotic component to density (Mouratidis 2018). \\
\hline \multirow[t]{4}{*}{$\begin{array}{l}\text { Mental } \\
\text { Health }\end{array}$} & Happy & $\begin{array}{l}\text { Happiness has been used interchangeably with wellbeing in the literature } \\
\text { and remains an essential component of good mental health (Smith 2018). }\end{array}$ \\
\hline & Stress & $\begin{array}{l}\text { As explored in the MRP, the urban realm produces a myriad of stresses on } \\
\text { its residents, each with a measurable biochemical signature (Park 2011). }\end{array}$ \\
\hline & Wellbeing & This keyword forms this MRP's thematic base. \\
\hline & Health & $\begin{array}{l}\text { This keyword is necessary because 'health' and 'wellbeing' are often used } \\
\text { interchangeably in the literature (Diener 2008). }\end{array}$ \\
\hline \multirow[t]{6}{*}{$\begin{array}{l}\text { Physical } \\
\text { Health }\end{array}$} & Active & $\begin{array}{l}\text { Urban residents that regularly engage in active transportation are shown to } \\
\text { have better physical health (USDHHS 1996). }\end{array}$ \\
\hline & Transport & $\begin{array}{l}\text { Works in tandem with the aforementioned 'active' keyword (Ross and } \\
\text { Dunning 1997). }\end{array}$ \\
\hline & Disease & $\begin{array}{l}\text { Specifically references 'non-communicable disease' as mentioned several } \\
\text { times in the MRP. The literature suggests that urban dwellers are } \\
\text { increasingly suffering from more non-communicable diseases (Kent and } \\
\text { Thompson 2014). }\end{array}$ \\
\hline & Illness & $\begin{array}{l}\text { Intended to potentially catch any references to physical wellbeing that the } \\
\text { 'disease' keyword missed (Kent and Thompson 2014). }\end{array}$ \\
\hline & Wellbeing & This keyword forms this MRP's thematic base. \\
\hline & Health & $\begin{array}{l}\text { This keyword is necessary because 'health' and 'wellbeing' are often used } \\
\text { interchangeably in the literature (Diener 2008). }\end{array}$ \\
\hline \multirow[t]{3}{*}{ Social Capital } & Social & $\begin{array}{l}\text { This keyword will serve as a general catch-all for any broad references to } \\
\text { social capital (Putnam 2000). }\end{array}$ \\
\hline & Gather & $\begin{array}{l}\text { Social spaces are places that allow urban residents to gather and engage } \\
\text { with one another. As such, this keyword is intended to pinpoint references } \\
\text { to this interpersonal relationship (Kent and Thompson 2014). }\end{array}$ \\
\hline & Interact & $\begin{array}{l}\text { Incidental interaction is a major component to healthy social capital in an } \\
\text { urban context, and the urban design of streets and spaces has the means to } \\
\text { catalyze this interaction (Mehta 2009). }\end{array}$ \\
\hline
\end{tabular}

Source: Developed by the author. 
After conducting the systematic keyword search, I will also provide an overall assessment of how the chosen Secondary Plans interact with the three built environment features - greenery, walkability, and density. This includes evaluating whether any trends exist in how the Plans refer to the built environment features and whether they are connected to any of the three dimensions of wellbeing as identified in the literature. If the Plans are making these links explicitly (i.e. the three built environment features are referenced as contributing to any of the three dimensions of wellbeing identified earlier), it would suggest that the City of Toronto is actively addressing the link between urban design and urban wellbeing. It is important to note, however, that even if the connections are not explicit references to the three built environment features, they will also be understood as indications of the City's engagement with urban wellbeing. Lastly, I will compare content analysis results from both Secondary Plan neighbourhoods and examine how the City of Toronto designed these Secondary Plans for different neighbourhoods in relation to the identified built environment concepts and the associated wellbeing impacts. If there are clear differences in approach between the two Plans in ways that suggest higher investment/more policy emphasis in York University Heights, it could indicate that the City is working to ameliorate a neighbourhood that may not have well-established urban design infrastructure that supports urban wellbeing. Contrarily, if the Yonge-Eglinton Secondary Plan seems to more consistently involve greenery, walkability, and density actions, it could suggest that the neighbourhood is treated as an priority economic area whose growth and profitability hinges on additional infrastructure and resources. 


\section{Content Analysis}

As explained at length in the previous sections, the literature review reinforced that much of the existing work regarding the improvement of urban wellbeing centres around the three dimensions of mental health, physical health, and social capital. The literature also consistently referenced the concepts of urban greenery, walkability, and density as having strong influences on urban wellbeing. Ultimately, each one of the built environment features can translate into potential urban design interventions that can create a public realm more conducive to wellbeing among residents. The York University Secondary Plan Table and Yonge-Eglinton Secondary Plan Table highlight the context where each keyword is referenced in the Secondary Plans, offer supporting quotations pulled from the Plans, and indicate how the keyword is mentioned in the document (vision, policy, implementation). If the keyword appears in a Plan's 'vision' section or subsequent policies, it will be labeled as such. The fact that a keyword appears in the vision of a Secondary Plan indicates a high-level acknowledgment of the idea. If the keyword appears in reference to additional policy, such as the construction of a precinct plan or City-wide guideline or strategy, it will be treated as a tool for implementation and be noted as such. Unlike references in the context of the Plan's vision, the fact that a keyword appears in the policy or actions section of a Secondary Plan indicates that it has been made an actionable objective and that the City is more strongly committed to its implementation. The full Content Analysis tables are below, and summary tables for each Secondary Plan can be found in the Appendix. 
York University Secondary Plan (2009)

Source: Developed by the author

\begin{tabular}{|c|c|c|c|c|c|c|c|}
\hline Concept & Keyword & Frequency & $\begin{array}{l}\text { Context(s) Where the Keyword } \\
\text { is Referenced in the Plan }\end{array}$ & Supporting Quotes & Vision & Policy & Implementation \\
\hline \multicolumn{8}{|l|}{$\begin{array}{l}\text { Urban Design } \\
\text { Interventions }\end{array}$} \\
\hline \multirow[t]{2}{*}{ Greenery } & Green & 23 & $\begin{array}{l}\text { - The Secondary Plan emphasizes } \\
\text { 'greenways': pedestrian corridors } \\
\text { that connect parks, heritage and } \\
\text { cultural features, } \\
\text { neighbourhoods, etc. (p. 24) } \\
\text { - A linked open space and natural } \\
\text { heritage system will be } \\
\text { developed. (p. 24) } \\
\text { - References green roofs and the } \\
\text { Toronto Green Standard. (p. 27) }\end{array}$ & $\begin{array}{l}\text { - "The Secondary Plan will protect and } \\
\text { improve the natural heritage features, } \\
\text { improve connectivity between the natural } \\
\text { heritage features and systems through } \\
\text { approaches such as green roofs, tree canopy } \\
\text { and ground level linkages and connect the } \\
\text { area's natural heritage features to the } \\
\text { broader natural heritage system." (p. } 6 \text { ) } \\
\text {-"The City's Green Standard sets } \\
\text { performance targets for new construction to } \\
\text { improve air and water quality, reduce green } \\
\text { house gas emissions and enhance the } \\
\text { natural environment. Some of these targets } \\
\text { can be directly achieved by incorporating } \\
\text { sustainable design features into the plans } \\
\text { and drawings submitted as part of the site } \\
\text { plan approval process." (p. 27) }\end{array}$ & & $\nabla$ & $\nabla$ \\
\hline & Park & $105^{*}$ & $\begin{array}{l}\text { - Envisions a connected, } \\
\text { complete community with high } \\
\text { quality parks and open places. (p. } \\
\text { 5) } \\
\text { - Parks will serve the entire city, } \\
\text { and all park spaces will } \\
\text { compliment active and passive } \\
\text { needs. (p. 26) } \\
\text { - Precinct plans will be developed } \\
\text { to ensure the construction of } \\
\text { comprehensive open space } \\
\text { systems. (p. 27) }\end{array}$ & $\begin{array}{l}\text { - "The park and open space system includes } \\
\text { parks and open spaces serving the entire } \\
\text { city, community parks serving the active } \\
\text { and passive recreational needs of persons } \\
\text { living, working and studying in the area, } \\
\text { parkettes or linear parks, and publicly } \\
\text { accessible and private open space and } \\
\text { recreation areas." (p. 26) } \\
\text {-A landscaping and open space master } \\
\text { plan will be developed for each precinct to } \\
\text { ensure a connected and comprehensive } \\
\text { open space system, to ensure the ongoing } \\
\text { vitality of open spaces in the Secondary } \\
\text { Plan area and to establish requirements for } \\
\text { new parks and open spaces established and } \\
\text { implemented through development." (p. 27) }\end{array}$ & $\nabla$ & $\nabla$ & $\nabla$ \\
\hline
\end{tabular}




\begin{tabular}{|c|c|c|c|c|c|c|c|}
\hline Concept & Keyword & Frequency & $\begin{array}{l}\text { Context(s) Where the Keyword } \\
\text { is Referenced in the Plan }\end{array}$ & Supporting Quotes & Vision & Policy & Implementation \\
\hline & Tree & 7 & $\begin{array}{l}\text { - References tree plantings and } \\
\text { tree canopy as a means to address } \\
\text { stormwater management and } \\
\text { provide wildlife and habitat } \\
\text { linkages. (p. } 6 \text { ) } \\
\text { - Trees are treated as an essential } \\
\text { component of identified } \\
\text { pedestrian-oriented streets. (p. } 10 \text {, } \\
\text { 12) } \\
\text { - The tree canopy will be } \\
\text { expanded across the Secondary } \\
\text { Plan's area. (p. } 27 \text { ) }\end{array}$ & $\begin{array}{l}\text { " "The Secondary Plan will protect and } \\
\text { improve the natural heritage features ... } \\
\text { through approaches such as green roofs, } \\
\text { tree canopy } \\
\text { and ground level linkages and connect the } \\
\text { area's natural heritage features to the } \\
\text { broader natural heritage system." (p. 6) } \\
\text { - "These streets will include wide } \\
\text { sidewalks, special tree and feature planting, } \\
\text { paving, street furniture, lighting and } \\
\text { signage." (p. 12) } \\
\text {-... identify opportunities for increasing } \\
\text { tree canopy coverage to } 30 \% \text { of the } \\
\text { Secondary Plan area and improving the } \\
\text { existing canopy." (p. 27) }\end{array}$ & & $\nabla$ & $\nabla$ \\
\hline Walkability & Walk & $20 *$ & $\begin{array}{l}\text { - The Secondary Plan area will } \\
\text { incorporate short walking } \\
\text { distances }(500 \mathrm{~m}) \text { from subway } \\
\text { stations. (p. 5) } \\
\text { - Convenient, safe, and weather- } \\
\text { protected pedestrian routes will } \\
\text { make walking more attractive. (p. } \\
\text { 29) } \\
\text { - Policy mandates a detailed } \\
\text { Pedestrian and Bicycle Plan at } \\
\text { the precinct planning stage that } \\
\text { will have regard to the Toronto } \\
\text { Walking Strategy. (p. 30) }\end{array}$ & $\begin{array}{l}\text { - "The Secondary Plan area will be planned } \\
\text { and designed to encourage walking and } \\
\text { cycling as viable modes of travel to reduce } \\
\text { the use of automobiles." (p. 29-30) } \\
\text { - "To ensure pedestrian and cyclist comfort } \\
\text { and safety, routes will be well-designed, } \\
\text { attractive, appropriately lit and maintained." } \\
\text { (p. 30) }\end{array}$ & & $\nabla$ & $\nabla$ \\
\hline
\end{tabular}




\begin{tabular}{|c|c|c|c|c|c|c|c|}
\hline Concept & Keyword & Frequency & $\begin{array}{l}\text { Context(s) Where the Keyword } \\
\text { is Referenced in the Plan }\end{array}$ & Supporting Quotes & Vision & Policy & Implementation \\
\hline & Street & $152 *$ & $\begin{array}{l}\text { - Policy maintains that streets } \\
\text { must be comfortable for } \\
\text { pedestrians; emphasis is placed } \\
\text { on pedestrian, cycling, and transit } \\
\text { movement (p. 3) } \\
\text { - Precinct Plans will outline street } \\
\text { design. Definitive language } \\
\text { ('must', 'will') is used when } \\
\text { referencing pedestrian-oriented } \\
\text { design elements. (p. 8-10) } \\
\text { - The vision prioritizes streets as } \\
\text { the setting for community life. } \\
\text { Streets are intended as people- } \\
\text { focused multi-purpose public } \\
\text { spaces. (p. 11) }\end{array}$ & $\begin{array}{l}\text { - "Streets are the setting for community life. } \\
\text { They are friendly and comfortable places } \\
\text { for pedestrians and cyclists. There are wider } \\
\text { sidewalks, and streets are lined with } \\
\text { benches shaded by boulevard trees where } \\
\text { people can sit and relax. Cars do not } \\
\text { dominate streets; rather, streets are multi- } \\
\text { purpose public spaces where people are the } \\
\text { focus." (p. 3-4) } \\
\text { - "It is about creating a complete, } \\
\text { sustainable community organized within a } \\
\text { high quality public realm of streets, parks } \\
\text { and open spaces, with the University acting } \\
\text { as the focal point for the area." (p. 11) }\end{array}$ & $\nabla$ & $\nabla$ & $\nabla$ \\
\hline & Distance & 8 & $\begin{array}{l}\text { - The Secondary Plan will create } \\
\text { higher-density, mixed-use } \\
\text { communities and office/research } \\
\text { areas within } \\
\text { a short walking distance ( } 500 \mathrm{~m}) \\
\text { from subway stations. (p. 5) } \\
\text { - New signage and wayfinding } \\
\text { elements will enhance the } \\
\text { pedestrian experience. (p. } 30) \\
\text { - New parkland is intended to } \\
\text { serve communities within a } \\
\text { reasonable walking distance. (p. } \\
\text { 58) }\end{array}$ & $\begin{array}{l}\text { - "Moreover, shorter walking distances to } \\
\text { major trip generators within the vicinity of } \\
\text { transit stations, such as office buildings, } \\
\text { recreational facilities or high-density } \\
\text { residential uses, provide an incentive for } \\
\text { people to take transit." (p. } 37 \text { ) } \\
\text { - "The principle adopted for density } \\
\text { permissions within the Secondary Plan area } \\
\text { is that the higher densities for non- } \\
\text { university uses should be located in close } \\
\text { proximity or within walking distance to } \\
\text { subway stations and that densities lessen } \\
\text { with distance from a subway station." (p. } \\
\text { 40) }\end{array}$ & & & \\
\hline
\end{tabular}




\begin{tabular}{|c|c|c|c|c|c|c|c|}
\hline Concept & Keyword & Frequency & $\begin{array}{l}\text { Context(s) Where the Keyword } \\
\text { is Referenced in the Plan }\end{array}$ & Supporting Quotes & Vision & Policy & Implementation \\
\hline \multirow[t]{2}{*}{ Density } & Density & 48 & $\begin{array}{l}\text { - Precinct plans designate varying } \\
\text { densities across the Secondary } \\
\text { Plan area. This is intended to } \\
\text { create compact, mixed-use nodal } \\
\text { communities that will also serve } \\
\text { the existing lower-density } \\
\text { residential communities } \\
\text { surrounding the University. (p. } \\
\text { 10) } \\
\text { - To encourage mixed-use, } \\
\text { transit-supportive development, } \\
\text { floor area associated with } \\
\text { identified desirable facilities will } \\
\text { be exempt from density } \\
\text { calculations where these facilities } \\
\text { are integrated within buildings. } \\
\text { (p. } 41 \text { ) }\end{array}$ & $\begin{array}{l}\text { • "Complete, transit supportive } \\
\text { communities should contain a mix of land } \\
\text { uses, density, built form and a range of } \\
\text { building heights ..." (p. 36) } \\
\text { • "Moreover, shorter walking distances to } \\
\text { major trip generators within the vicinity of } \\
\text { transit stations, such as office buildings, } \\
\text { recreational facilities or high-density } \\
\text { residential uses, provide an incentive for } \\
\text { people to take transit." (p. 37) } \\
\text { • "The principle adopted for density } \\
\text { permissions within the Secondary Plan area } \\
\text { is that the higher densities for non- } \\
\text { university uses should be located in close } \\
\text { proximity or within walking distance to } \\
\text { subway stations and that densities lessen } \\
\text { with distance from a subway station." (p. } \\
\text { 40) }\end{array}$ & & $\nabla$ & $\nabla$ \\
\hline & Height & 29 & $\begin{array}{l}\text { - Street related development will } \\
\text { have building bases that are } \\
\text { developed at a pedestrian-scale } \\
\text { height. (p. } 38 \text { ) } \\
\text { - Minimum building heights for } \\
\text { buildings fronting key and } \\
\text { secondary streets are listed. (p. } \\
\text { 43) }\end{array}$ & $\begin{array}{l}\text { - "The heights of new buildings will respect } \\
\text { important views, the height and built form } \\
\text { of existing institutional buildings and other } \\
\text { spatial and structural elements of the } \\
\text { University." (p. 8) } \\
\text { - "A range of building heights provides for } \\
\text { a more interesting and varied built form that } \\
\text { respects the existing character of a } \\
\text { particular area and provides appropriate } \\
\text { height transitions to lower-scale } \\
\text { development. Building heights also have a } \\
\text { role in shaping the street-level experience } \\
\text { for pedestrians." (p. 42) }\end{array}$ & & $\nabla$ & $\nabla$ \\
\hline \multicolumn{8}{|l|}{$\begin{array}{l}\text { Dimensions of } \\
\text { Wellbeing }\end{array}$} \\
\hline \multirow{3}{*}{$\begin{array}{l}\text { Mental } \\
\text { Health }\end{array}$} & Happy & 0 & N/A & $\mathrm{N} / \mathrm{A}$ & . & 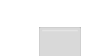 & 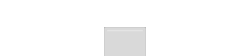 \\
\hline & Stress & 0 & N/A & N/A & & & $\square$ \\
\hline & Wellbeing & 0 & N/A & N/A & 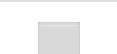 & & 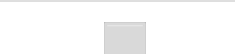 \\
\hline
\end{tabular}




\begin{tabular}{|c|c|c|c|c|c|c|c|}
\hline Concept & Keyword & Frequency & $\begin{array}{l}\text { Context(s) Where the Keyword } \\
\text { is Referenced in the Plan }\end{array}$ & Supporting Quotes & Vision & Policy & Implementation \\
\hline & Health & 0 & N/A & N/A & & & \\
\hline \multirow[t]{6}{*}{$\begin{array}{l}\text { Physical } \\
\text { Health }\end{array}$} & Active & 8 & $\begin{array}{l}\text { - Development in the Secondary } \\
\text { Plan area will encourage active } \\
\text { ground floor uses. (p. 9) } \\
\text { - Community parks will serve } \\
\text { active and passive recreational } \\
\text { uses. (p. 26) }\end{array}$ & $\begin{array}{l}\text { " The Central Campus Precinct is the focus } \\
\text { of the University. It has the highest } \\
\text { concentration of university uses and is the } \\
\text { most active pedestrian environment." (p. } 8 \text { ) } \\
\text { - "The areas shown as Parks will be } \\
\text { developed, landscaped and maintained to } \\
\text { provide space for active and passive } \\
\text { recreational purposes." (p. 40) }\end{array}$ & & $\nabla$ & $\nabla$ \\
\hline & Transport & 29 & $\begin{array}{l}\text { - Primary streets will balance } \\
\text { their transportation function with } \\
\text { their role as public spaces, } \\
\text { linking open spaces and the City. } \\
\text { (p. 32) } \\
\text { - Transportation Demand } \\
\text { Management will be encouraged } \\
\text { to reduce car dependency. (p. 33) } \\
\text { - A Transportation Master Plan is } \\
\text { in place to guide the } \\
\text { transportation infrastructure } \\
\text { required to service the predicted } \\
\text { growth. (p. 47) }\end{array}$ & $\begin{array}{l}\text { - "The future development of the Secondary } \\
\text { Plan area is linked directly to providing a } \\
\text { connected transportation framework that } \\
\text { allows residents, employees and students to } \\
\text { get to and from their desired destinations } \\
\text { quickly, easily and sustainably." (p. 28) } \\
\text { - "... this Secondary Plan also focuses on } \\
\text { encouraging other sustainable modes of } \\
\text { transportation, such as walking and cycling, } \\
\text { while reducing the use of the private } \\
\text { automobile and providing a balanced } \\
\text { approach to parking." (p. 29) }\end{array}$ & & $\nabla$ & $\nabla$ \\
\hline & Disease & 0 & N/A & N/A & & & \\
\hline & Illness & 0 & N/A & N/A & & & \\
\hline & Wellbeing & 0 & N/A & N/A & 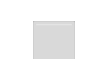 & 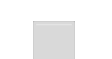 & \\
\hline & Health & $1 *$ & $\begin{array}{l}\text { - A high-level reference to } \\
\text { personal health is made in the } \\
\text { Plan's community services and } \\
\text { facilities vision. (p. 2) }\end{array}$ & $\begin{array}{l}\text { "A strong network of community services } \\
\text { is essential to maintaining and enhancing } \\
\text { the health, safety and well-being of } \\
\text { students, faculty, residents and employees } \\
\text { in the Secondary Plan area ..." (p. 2) }\end{array}$ & $\nabla$ & & \\
\hline
\end{tabular}




\begin{tabular}{|c|c|c|c|c|c|c|c|}
\hline Concept & Keyword & Frequency & $\begin{array}{l}\text { Context(s) Where the Keyword } \\
\text { is Referenced in the Plan }\end{array}$ & Supporting Quotes & Vision & Policy & Implementation \\
\hline \multirow[t]{3}{*}{ Social Capital } & Social & $10^{*}$ & $\begin{array}{l}\text { - Policy ensures that community } \\
\text { services and facilities contribute } \\
\text { to } \\
\text { the area's social, economic and } \\
\text { environmental health. (p. 22) } \\
\text { - Affordable, accessible, and high } \\
\text { quality community services will } \\
\text { encourage equity and social } \\
\text { cohesion. (p. 22) } \\
\text { - A Pedestrian and Bicycle Plan } \\
\text { will help socially and physically } \\
\text { knit together the Secondary Plan } \\
\text { area with its surrounding } \\
\text { community (p. 30) }\end{array}$ & $\begin{array}{l}\text { - "Enhanced physical, social and visual } \\
\text { connections to the surrounding city will not } \\
\text { diminish the distinctive character of } \\
\text { the University ..." (p. 6) } \\
\text { - "A broad range of housing opportunities } \\
\text { will provide residents with the ability to } \\
\text { remain in their communities and retain their } \\
\text { connections and social networks as their } \\
\text { housing needs change." (p. 19) } \\
\text { - "These streets, including York Boulevard, } \\
\text { function like public streets by providing } \\
\text { access, address, open space and social } \\
\text { amenity to University buildings." (p. } 31 \text { ) }\end{array}$ & $\nabla$ & $\sqrt{ }$ & $\nabla$ \\
\hline & Gather & 1 & $\begin{array}{l}\text { The Plan notes a need to } \\
\text { provide a central, public } \\
\text { gathering space for residents. (p. } \\
\text { 10) }\end{array}$ & $\begin{array}{l}\text { " "A neighbourhood town square, piazza or } \\
\text { "neighbourhood centre" should be located } \\
\text { in this precinct to provide social gathering } \\
\text { opportunities, a sense of place and an } \\
\text { identity for this precinct." (p. 10) }\end{array}$ & & & $\nabla$ \\
\hline & Interact & 4 & $\begin{array}{l}\text { - Interaction is referenced } \\
\text { between neighbourhood } \\
\text { residents, employees, and } \\
\text { students, but also between the } \\
\text { University and City as a whole. } \\
\text { (p. } 57 \text { ) }\end{array}$ & $\begin{array}{l}\text { - "[The 'neighbourhood centre'] should be } \\
\text { located and designed as a catalyst for } \\
\text { resident, employee and student interaction } \\
\text { as well as provide opportunities to host } \\
\text { community events." (p. 10) }\end{array}$ & & & $\nabla$ \\
\hline
\end{tabular}

* Indicates a keyword that appeared more frequently than recorded in the table. Certain uses of the keyword did not pertain to the keyword in context of the table and subsequently inflated the result. Consequently, these outliers were omitted from the final tally. For example, the keyword 'park' was found to reference both 'park spaces' and 'parking'. 
Yonge-Eglinton Secondary Plan (2014)

Source: Developed by the author

\begin{tabular}{|c|c|c|c|c|c|c|c|}
\hline Concept & Keyword & Frequency & $\begin{array}{l}\text { Context(s) Where the Keyword } \\
\text { is Referenced in the Plan }\end{array}$ & Supporting Quotes & Vision & Policy & Implementation \\
\hline \multicolumn{8}{|c|}{$\begin{array}{l}\text { Urban Design } \\
\text { Interventions }\end{array}$} \\
\hline \multirow[t]{3}{*}{ Greenery } & Green & 1 & $\begin{array}{l}\text { - Parkland and public space will } \\
\text { be linked through multi-modal } \\
\text { connections. (p. } 3 \text { ) }\end{array}$ & $\begin{array}{l}\text { "Provide connections between public } \\
\text { parkland and open spaces in the Yonge- } \\
\text { Eglinton area, and to similar resources in } \\
\text { adjacent areas, through the use of trails, } \\
\text { bikeways, pedestrian-friendly streetscape } \\
\text { environments, walkways and } \\
\text { greenbelts." (p. 3) }\end{array}$ & $\sqrt{ }$ & & \\
\hline & Park & $20 *$ & $\begin{array}{l}\text { - The Plan's policy offers nine } \\
\text { methods of improving the } \\
\text { distribution and supply of parks } \\
\text { within the Secondary Plan area. } \\
\text { (p. 3) } \\
\text { - Priority Section } 37 \text { Community } \\
\text { Benefits to secure include public } \\
\text { parkland and park improvements } \\
\text { in excess of required parkland } \\
\text { dedications under Section 42." (p. } \\
\text { 5) }\end{array}$ & $\begin{array}{l}\text { - "Secure land for new local parks in areas } \\
\text { with a low rate of local parkland provision } \\
\text { as shown on Map } 8(\mathrm{~B}) . " \text { (p. 3) } \\
\text { - "... encourage the development of street } \\
\text { parks through the provision of trees, } \\
\text { benches, planters and other appropriate } \\
\text { street furniture." (p. 3). } \\
\text { - "To strengthen the community focus a } \\
\text { public park and community facilities should } \\
\text { be established in the southwest quadrant of } \\
\text { the Yonge-Eglinton intersection in a timely } \\
\text { fashion." (p. 5) }\end{array}$ & & $\nabla$ & \\
\hline & Tree & 0 & N/A & N/A & & & $\square$ \\
\hline Walkability & Walk & $1 *$ & $\begin{array}{l}\text { - Urban design considerations for } \\
\text { enhanced walkability will be } \\
\text { taken into account as new } \\
\text { developments are constructed in } \\
\text { the Secondary Plan area. }\end{array}$ & $\begin{array}{l}\text { "The City will promote the design of new } \\
\text { development which encourages travel by } \\
\text { walking, cycling and transit." (p. 2) }\end{array}$ & & & \\
\hline
\end{tabular}




\begin{tabular}{|c|c|c|c|c|c|c|c|}
\hline Concept & Keyword & Frequency & $\begin{array}{l}\text { Context(s) Where the Keyword } \\
\text { is Referenced in the Plan }\end{array}$ & Supporting Quotes & Vision & Policy & Implementation \\
\hline & Street & $15^{*}$ & $\begin{array}{l}\text { - Pedestrian oriented street- } \\
\text { related retail will be retained and } \\
\text { encouraged. (p. 1) } \\
\text { - Public realm improvements will } \\
\text { include enhancements to } \\
\text { streetscapes, existing open } \\
\text { spaces, and wider sidewalks. } \\
\text { Larger building setbacks will be } \\
\text { considered as new developments } \\
\text { are proposed. (p. } 2-3)\end{array}$ & $\begin{array}{l}\text { - "The development of mixed use buildings } \\
\text { in Mixed Use Areas will be encouraged to } \\
\text { increase active pedestrian circulation at } \\
\text { street level, and to increase housing } \\
\text { opportunities for family and other } \\
\text { households." (p. 1) } \\
\text { - "It is a further objective to encourage that } \\
\text { access points, the relationship of } \\
\text { development to the sidewalk and the } \\
\text { location of walls, fences and trees enhance } \\
\text { the quality of the streetscape." (p. 4) }\end{array}$ & $\nabla$ & & \\
\hline & Distance & 1 & $\begin{array}{l}\text { - Building height and massing } \\
\text { will be highest at and around the } \\
\text { Yonge-Eglinton intersection. (p. } \\
6 \text { ) }\end{array}$ & $\begin{array}{l}\text { - "The heights, densities and scale of } \\
\text { development will decrease along Eglinton } \\
\text { Avenue East with increasing distance from } \\
\text { the Yonge-Eglinton intersection within the } \\
\text { Yonge-Eglinton Centre." (p. 6) }\end{array}$ & & $\nabla$ & \\
\hline \multirow[t]{2}{*}{ Density } & Density & 6 & $\begin{array}{l}\text { - The Yonge-Eglinton intersection } \\
\text { will continue to intensify as a } \\
\text { transportation and commercial } \\
\text { focal point in the Secondary Plan } \\
\text { area. (p. 4) }\end{array}$ & $\begin{array}{l}\text { "Direct higher density residential } \\
\text { development proposals within the } \\
\text { Apartment Neighbourhoods to sites with } \\
\text { nearby subway station access." (p. 2) }\end{array}$ & & $\nabla$ & \\
\hline & Height & 16 & $\begin{array}{l}\text { - New development will provide } \\
\text { a sensitive transition in height, } \\
\text { density and scale through } \\
\text { building setbacks and stepbacks } \\
\text { from the zoned height limit to the } \\
\text { zoned height of the adjacent } \\
\text { lands in designated } \\
\text { neighbourhoods. (p. 9) }\end{array}$ & $\begin{array}{l}\text { - "In considering new development } \\
\text { proposals, particular regard will be had in } \\
\text { avoiding adverse impacts resulting from } \\
\text { height, scale and density, on abutting } \\
\text { Neighbourhoods and on other Mixed Use } \\
\text { Areas." (p. 4) }\end{array}$ & & & \\
\hline \multicolumn{8}{|l|}{$\begin{array}{l}\text { Dimensions of } \\
\text { Wellbeing }\end{array}$} \\
\hline \multirow{3}{*}{$\begin{array}{l}\text { Mental } \\
\text { Health }\end{array}$} & Happy & 0 & $\mathrm{~N} / \mathrm{A}$ & $\mathrm{N} / \mathrm{A}$ & & & 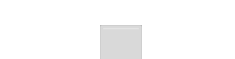 \\
\hline & Stress & 0 & $\mathrm{~N} / \mathrm{A}$ & N/A & & & 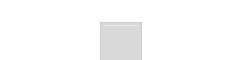 \\
\hline & Wellbeing & 0 & N/A & N/A & & & $\square$ \\
\hline
\end{tabular}




\begin{tabular}{|c|c|c|c|c|c|c|c|}
\hline Concept & Keyword & Frequency & $\begin{array}{l}\text { Context(s) Where the Keyword } \\
\text { is Referenced in the Plan }\end{array}$ & Supporting Quotes & Vision & Policy & Implementation \\
\hline & Health & 0 & N/A & N/A & & & \\
\hline \multirow[t]{6}{*}{$\begin{array}{l}\text { Physical } \\
\text { Health }\end{array}$} & Active & 1 & $\begin{array}{l}\text { - Policy efforts are being made to } \\
\text { ensure a lively, active public } \\
\text { realm in the Secondary Plan area. } \\
\text { (p. 1) }\end{array}$ & $\begin{array}{l}\text { - "The development of mixed use buildings } \\
\text { in Mixed Use Areas will be encouraged to } \\
\text { increase active pedestrian circulation at } \\
\text { street level, and to increase housing } \\
\text { opportunities for family and other } \\
\text { households." (p. 1) }\end{array}$ & & $\nabla$ & \\
\hline & Transport & 8 & $\begin{array}{l}\text { - New developments will be } \\
\text { encouraged to consider } \\
\text { implementation of sustainable } \\
\text { transportation initiatives, } \\
\text { including, but not limited to: } \\
\text { enhanced facilities for bicycle } \\
\text { users; entrance connections to } \\
\text { transit facilities; and bulk } \\
\text { purchase of transit passes to } \\
\text { minimize the potential } \\
\text { incremental impact of vehicular } \\
\text { traffic in the area. (p. } 2 \text { ) }\end{array}$ & $\begin{array}{l}\text { - "Major development proposals will be } \\
\text { subject to the City of Toronto's } \\
\text { Transportation Impact Study requirements } \\
\text { and, where appropriate, Transportation } \\
\text { Demand Management Study requirements." } \\
\text { (p. 2) }\end{array}$ & & & \\
\hline & Disease & 0 & N/A & N/A & & & \\
\hline & Illness & 0 & $\mathrm{~N} / \mathrm{A}$ & $\mathrm{N} / \mathrm{A}$ & & & $\square$ \\
\hline & Wellbeing & 0 & $\mathrm{~N} / \mathrm{A}$ & N/A & 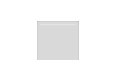 & & 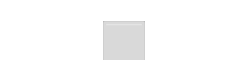 \\
\hline & Health & 0 & N/A & N/A & 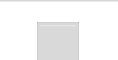 & & 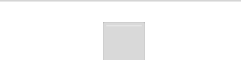 \\
\hline Social Capital & Social & 3 & $\begin{array}{l}\text { - Community Service facilities } \\
\text { will be developed in tandem with } \\
\text { new developments to ensure that } \\
\text { social infrastructure is accounted } \\
\text { for. (p. 4) } \\
\text { - Community and recreation } \\
\text { facilities will be excluded from } \\
\text { the calculation of density from } \\
\text { projects within Mixed Use Area } \\
\text { 'A'. (p. 5) }\end{array}$ & $\begin{array}{l}\text { "Community service facilities will be } \\
\text { delivered in a timely manner in order to } \\
\text { provide the social infrastructure required to } \\
\text { support additional growth in the Yonge- } \\
\text { Eglinton Secondary Plan area." (p. 3) }\end{array}$ & & & \\
\hline
\end{tabular}




\begin{tabular}{|l|l|c|l|l|l|}
\hline Concept & Keyword & Frequency & $\begin{array}{c}\text { Context(s) Where the Keyword } \\
\text { is Referenced in the Plan }\end{array}$ & Supporting Quotes \\
\hline & Gather & 0 & N/A & N/A \\
\hline & Interact & 0 & N/A & N/A \\
\hline
\end{tabular}

* Indicates a keyword that appeared more frequently than recorded in the table. Certain uses of the keyword did not pertain to the keyword in context of the table and subsequently inflated the result. Consequently, these outliers were omitted from the final tally. For example, the keyword 'park' was found to reference both 'park spaces' and 'parking'. 


\section{York University Secondary Plan}

The York University Secondary Plan provides substantially more design depth than the Yonge-Eglinton Secondary Plan. As a result, it is possible to identify a broader range of keywords more consistently through the document's sections, and the document more clearly establishes a link between core policy themes and the three built environment features explored in this MRP (see York University Secondary Plan (2009) table). The Plan's greatest strengths rest in its focus on creating linked parks and open spaces, and emphasizing pedestrian-oriented street design (pages 3, 8-11). These two urban design interventions have significant ties not only to the built environment features of greenery and walkability, but also to the dimensions of mental health and physical health identified in the literature (Park 2011, USDHHS 1996). More explicitly, the Plan hopes to engage more of the neighbourhood's residents in active and alternative forms of transportation (pages 32-33), and it also accounts for the social infrastructure that is necessary for healthy neighbourhoods as they continue to grow. Community services and facilities will contribute to community wellbeing (pages 10,22), and a human-scale public realm will help hone social connections between precincts and the surrounding communities (pages 30, 57). By making these links between physical health, social capital, and the design of York University's built form, the City of Toronto is showing a commitment to actively addressing the link between urban design and urban wellbeing through enforceable planning instruments that help provide urban design infrastructure to support urban wellbeing.

\section{Yonge-Eglinton Secondary Plan}


Contrarily, the Yonge-Eglinton Secondary Plan is much sparser in terms of referencing wellbeing keywords (see Yonge-Eglinton Secondary Plan (2014) table). It advocates for additional park spaces and streetscape improvements (pages 2-3,5), but offers little concrete direction for how to accomplish this. The language used in this Plan tends to be visionary in character, but most of the document is dedicated to broad-stroke policy direction for acquiring parkland and managing levels of density from the area's core to the surrounding neighbourhood zones (pages 4, 9). Most importantly, this Plan does not provide guidance for actual policy implementation. Without any tools to help transpose the Plan's vision into concrete action, there is little that truly holds the Plan accountable to what it seeks to do. This could hint that perhaps the City holds less of a commitment to structuring Yonge-Eglinton's growth. This could be true for two reasons: (1) Yonge-Eglinton already scores high on Wellbeing Toronto's index, and as such, the City may find it more pertinent to dedicate its planning resources elsewhere, or; (2) the neighbourhood is adequately intensifying as is and its planning framework appropriately accounts for the wellbeing infrastructure necessary to maintain its current wellbeing standing.

\section{Comparing the Secondary Plans}

The two Secondary Plans take significantly different approaches to their organization and execution. Whereas Yonge-Eglinton is governed by loose policies that use language like 'encourage' and 'can' (see Plan sections 2.5, 2.8, 2.9), York University's Secondary Plan hinges on definitive expectations like 'must' and 'will' (see Plan sections 2.1, 2.2, 3.1). York University's drive for action is echoed in how its message and goals are consistently enacted through vision, policy, and devices for implementation (see York University Secondary Plan 
(2009) table). The Plan stands on its own but is also reinforced through additional City

guidelines and initiatives (pages 27, 30), ultimately creating a methodological framework for the neighbourhood's growth.

Generally, the keywords 'park' and 'street' along with the density-related keywords of 'density' and 'height' were most often referenced between the two Secondary Plans. However, the York University Secondary Plan references them substantially more than the Yonge-Eglinton Secondary Plan. For example, 'park', 'street', 'density', and 'height' are respectively referenced 105, 152, 48, and 29 times in the York University Secondary Plan (see York University Secondary Plan (2009) table), but only 20, 15, 6, and 16 times in the Yonge-Eglinton Secondary Plan (see Yonge-Eglinton Secondary Plan (2014) table).

The Yonge-Eglinton Secondary Plan alludes to public realm improvements related to greenery, walkability, and density (see Plan sections 2.16, 2.21, 2.7), but fails to link them with the dimensions of wellbeing. It also tends to remain at the visionary level by providing inconsistent policy direction and failing to make any connections to methods of implementation (see Yonge-Eglinton Secondary Plan (2014) table). Contrarily, the York University Secondary Plan makes specific mention to built environment concepts and how their designed features will impact the area's physical realm. For example, improvements to walkability are enacted through overarching principles that seek to develop the area as an increasingly compact community with designated pedestrian-oriented infrastructure and amenities that encourage active pedestrian life (see Plan sections $2.1,3.1,3.9$ ). These objectives are ultimately translated into action through clearly referenced methods of implementation (see York University Secondary Plan (2009) table). This is paired with guiding principles that strive to improve the physical health and social 
connections of neighbourhood residents, and it combines to create a holistic approach towards relating built environment concepts with their associated wellbeing impacts. As a whole, it feels as though the City of Toronto is taking calculated leaps towards developing the York University study area to ensure that it grows alongside infrastructure that supports wellbeing along the lines identified in the literature informing this MRP.

\section{Conclusion}

This MRP started from the assumption that the notion of wellbeing in an urban context is very complex and multifaceted. City dwellers are folding under the burden of mental and physical stresses (Park 2011, Smith 2018), and increasingly threatened local social networks (ComRes 2013, Montgomery 2013). While fostering urban wellbeing exceeds the scope of urban planning alone, the planning and design disciplines are well positioned to mediate these issues in increasingly intensifying urban areas. This MRP's in-depth literature review has reaffirmed that the design features of urban greenery, walkability, and the smart use of density are not only strong factors influencing of improved personal and community wellbeing, but components of healthier cities overall. As individual design interventions, they were the most positively linked in relation to urban wellbeing and could conceptually form the foundation of 'wellbeing infrastructure'. When combined holistically through effective policy, they can hold transformative effects across a city.

The two Secondary Plans examined in this MRP offered a glimpse into how the City handles built form and urban design. Through a systematic analysis of the two documents, it was most interesting to see how varied their approaches were. This was especially true regarding how 
intensely and specifically growth was being guided in the York University study area. However, it must be noted that neither of the Secondary Plans made explicit reference to the keywords 'happy', 'stress', 'wellbeing', 'health', 'disease', or 'illness'. The literature continually referred to these as components of health in the broader pursuit of wellbeing, and their absence in the Plans might indicate that the City of Toronto lacks awareness, research, or policy direction as to why these are important considerations and how they can foster a healthier city. This gap is certainly a potential area for improvement for the City, and it is one that could be instrumental in creating a healthier, happier city.

The City of Toronto does appear to be taking an active role to support the physical and mental wellbeing of urban residents through thoughtful urban design considerations. In addressing and accounting for urban greenery, walkability, and the smart use of density, the City is also implementing the built infrastructure necessary to improving urban wellbeing. The dimensions of mental health, physical health, and social capital may be personal variables, but they are undeniably strongly influenced by the physical composition of urban built form. Each built environment concept and design intervention examined in this MRP not only plays a mutually reinforcing role in urban wellbeing, but also plays a broader in creating healthier cities overall. 


\section{APPENDIX}

York University Secondary Plan Summary

\begin{tabular}{|c|c|c|c|}
\hline & Urban Greenery & Walkability & Density \\
\hline Mental Health & $\begin{array}{l}\text { - Precinct plans will be } \\
\text { developed to ensure the } \\
\text { construction of comprehensive } \\
\text { open space systems. (p. 27) } \\
\text { - Trees are treated as an } \\
\text { essential component of } \\
\text { identified pedestrian-oriented } \\
\text { streets. (p. } 10,12 \text { ) }\end{array}$ & $\begin{array}{l}\text { - New parkland is intended to } \\
\text { serve communities within a } \\
\text { reasonable walking distance. } \\
\text { (p. 58) }\end{array}$ & \\
\hline Physical Health & $\begin{array}{l}\text { Parks will serve the entire } \\
\text { city, and all park spaces will } \\
\text { compliment active and passive } \\
\text { needs. (p. 26) }\end{array}$ & $\begin{array}{l}\text { - Primary streets will balance } \\
\text { their transportation function } \\
\text { with their role as public } \\
\text { spaces, linking open spaces } \\
\text { and the City. (p. 32) } \\
\text { - Policy maintains that streets } \\
\text { must be comfortable for } \\
\text { pedestrians; emphasis is } \\
\text { placed on pedestrian, cycling, } \\
\text { and transit movement (p. 3) }\end{array}$ & \\
\hline Social Capital & $\begin{array}{l}\text { - The Secondary Plan } \\
\text { emphasizes 'greenways': } \\
\text { pedestrian corridors that } \\
\text { connect parks, heritage and } \\
\text { cultural features, } \\
\text { neighbourhoods, etc. (p. } 24 \text { ) } \\
\text { - The vision prioritizes streets } \\
\text { as the setting for community } \\
\text { life. Streets are intended as } \\
\text { people-focused multi-purpose } \\
\text { public spaces. (p. } 11 \text { ) }\end{array}$ & $\begin{array}{l}\text { The vision prioritizes streets } \\
\text { as the setting for community } \\
\text { life. Streets are intended as } \\
\text { people-focused multi-purpose } \\
\text { public spaces. (p. 11) }\end{array}$ & $\begin{array}{l}\text { - Street related development } \\
\text { will have building bases that } \\
\text { are developed at a pedestrian- } \\
\text { scale height. (p. } 38 \text { ) } \\
\text { - Interaction is referenced } \\
\text { between neighbourhood } \\
\text { residents, employees, and } \\
\text { students, but also between the } \\
\text { University and City as a } \\
\text { whole. (p. } 57 \text { ) }\end{array}$ \\
\hline
\end{tabular}


Yonge-Eglinton Secondary Plan Summary

\begin{tabular}{|c|c|c|c|}
\hline & Urban Greenery & Walkability & Density \\
\hline Mental Health & $\begin{array}{l}\text { - The Plan's policy offers nine } \\
\text { methods of improving the } \\
\text { distribution and supply of } \\
\text { parks within the Secondary } \\
\text { Plan area. (p. 3) }\end{array}$ & & \\
\hline Physical Health & & $\begin{array}{l}\text { Policy efforts are being } \\
\text { made to ensure a lively, } \\
\text { active public realm in the } \\
\text { Secondary Plan area. (p. } 1 \text { ) }\end{array}$ & $\begin{array}{l}\text { - New developments will be } \\
\text { encouraged to consider } \\
\text { implementation of sustainable } \\
\text { transportation initiatives, } \\
\text { including, but not limited to: } \\
\text { enhanced facilities for bicycle } \\
\text { users; entrance connections to } \\
\text { transit facilities; and bulk } \\
\text { purchase of transit passes to } \\
\text { minimize the potential } \\
\text { incremental impact of } \\
\text { vehicular traffic in the area. } \\
\text { (p. 2) }\end{array}$ \\
\hline Social Capital & & $\begin{array}{l}\text { - Public realm improvements } \\
\text { will include enhancements to } \\
\text { streetscapes, existing open } \\
\text { spaces, and wider sidewalks. } \\
\text { Larger building setbacks will } \\
\text { be considered as new } \\
\text { developments are proposed. } \\
\text { (p. } 2-3 \text { ) }\end{array}$ & $\begin{array}{l}\text { - Community Service } \\
\text { facilities will be developed in } \\
\text { tandem with new } \\
\text { developments to ensure that } \\
\text { social infrastructure is } \\
\text { accounted for. (p. } 4 \text { ) }\end{array}$ \\
\hline
\end{tabular}




\section{REFERENCES}

Abedi, Maham. 2018. "Canadians aren't nearly as active as they think they are: survey." Global News. Retrieved January 242019 from https://globalnews.ca/news/4777241/canadiansphysical-activity-survey/.

Abraham, A., K. Sommerhalder, and T. Abel. 2010. "Landscape and Well-Being: A Scoping Study on the Health-Promoting Impact of Outdoor Environments." International Journal of Public Health 55(1):59-69.

Adams, Mags. 2014. "Quality of Urban Spaces and Wellbeing." Pp. 249-270 in Wellbeing and the Environment: Wellbeing: A Complete Reference Guide, Volume II. Hoboken, NJ: John Wiley \& Sons, Ltd.

Allen, Mike. 2017. "Axial Coding." in The SAGE Encyclopedia of Communication Research Methods. Los Angeles: Sage Publications.

Anderson, Jamie, Kai Ruggeri, Koen Steemers, and Felicia Huppert. 2017. "Lively Social Space, Well-Being Activity, and Urban Design: Findings From a Low-Cost Community-Led Public Space Intervention." Environment and Behaviour 49(6):685-716.

Bauman, A. E., R. S. Reis, J. F. Sallis, J. C. Wells, R. J. Loos, and B. W. Martin. 2012. "Correlates of physical activity: why are some people physically active and others not?" The Lancet 380(9838):258-271.

Berry, Brian J. L. and Adam Okulicz-Kozaryn. 2011. "An Urban-Rural Happiness Gradient.” Urban Geography 32:871-883.

Beutel, Manfred E., Claus Jünger, Eva M. Klein, Phillipp Wild, Karl Lackner, Maria Blettner, Harald Binder, Matthias Michal, Jörg Wiltink, Elmar Brähler, and Thomas Münzel. 2016. "Noise Association Is Associated with Depression and Anxiety in the General Population - The Contribution of Aircraft Noise." PLoS 11(5).

Chawla, Louise. 2002. Growing up in an urbanizing world. London: Earthscan.

Chee Keng Lee, Andrew, Hannah C. Jordan, and Jason Horsley. 2015. "Value of urban green spaces in promoting healthy living and wellbeing: prospects for planning." Risk Management and Healthcare Policy 8:131-137.

City of Toronto. 2009. "York University Secondary Plan." Retrieved April 12, 2019 from https:// www.toronto.ca/wp-content/uploads/2017/11/9219-cp-official-plan-SP-10YorkUniversity.pdf. 
City of Toronto. 2014. "Yonge-Eglinton Secondary Plan.” Retrieved April 12, 2019 from https:// www.toronto.ca/wp-content/uploads/2017/11/97ea-cp-official-plan-SP-21YongeEglinton.pdf.

City of Toronto. 2015. "Green city: Why Nature Matters to Health.” Medical Officer of Health. Retrieved January 15, 2019 from https:/www.toronto.ca/legdocs/mmis/2015/hl/bgrd/ backgroundfile-83420.pdf.

City of Toronto. 2015. “Official Plan.” Toronto City Planning. Retrieved April 12, 2019 from https:/www.toronto.ca/city-government/planning-development/official-plan-guidelines/ official-plan/.

City of Toronto. 2017. "Wellbeing Toronto." Social Research. Retrieved April 12, 2019 from https://www.toronto.ca/city-government/data-research-maps/neighbourhoodscommunities/wellbeing-toronto/.

City of Toronto. 2019. “TOCore Planning Downtown: University Avenue.” TOCore.

Cloutier, Scott, Lincoln Larson, and Jenna Jambeck. 2014. “Are sustainable cities 'happy' cities? Associations between sustainable development and human well-being in urban areas of the United States.” Environment, Development and Sustainability 16:633-647.

Cohen, D. A., S. Inagami, and B. Finch. 2008. "The Built Environment and Collective Efficacy." Health and Place 14(2):198-208.

Commission for Architecture and the Built Environment. 2009. Future health: Sustainable places for health and well-being. London: CABE.

ComRes. 2013. "BBC Religion Loneliness Study.” BBC Radio 2.

Cui, Yutong, Anna L. Hansell, Marta Blangiardo, Paul R. Burton, BioSHaRE, Kees de Hoogh, Dany Doiron, Isabel Fortier, John Gulliver, Kristian Hveem, Stéphane Mbatchou, David W. Morley, Ronald P. Stolk, Wilma L. Zijlema, Paul Elliott, and Susan Hodgson. 2017. "Long-term exposure to road traffic noise, ambient air pollution, and cardiovascular risk factors in the HUNT and lifelines cohorts." European Heart Journal 38(29):2290-2296.

Douglas, Owen, Mick Lennon, and Mark Scott. 2017. "Green space benefits for health and wellbeing: A life-course approach for urban planning, design and management." Cities 66:53-62.

Easterlin, Richard A. 2003. "Explaining Happiness." Proceedings of the National Academy of Sciences of the United States of America 100:11,176-11,183. 
Ellard, Colin. 2012. "Stress and the City." Retrieved December 27, 2018 (https:// www.psychologytoday.com/intl/blog/mind-wandering/201208/stress-and-the-city).

Ereaut, Gill and Rebecca Whiting. 2008. "What do we mean by 'wellbeing'? And why might it matter?" London: Department for Children, Schools and Families.

Evans, G. W. 2003. “The Built Environment and Mental Health.” Journal of Urban Health 80(4):536-555.

Ferreira, Becky. 2017. "We Need to Design Less Stressful Cities." Retrieved December 27, 2018 (https://motherboard.vice.com/en_us/article/vb3bxx/we-need-to-design-less-stressfulcities-stressweek2017).

Festinger, Leon, Kurt W. Back, and Stanley Schachter. 1950. Social pressures in informal groups: A study of human factors in housing. Stanford, CA: Stanford University Press, 1963.

Flyvbjerg, Bent. 2011. "Case Study" Pp. 301-316 in The Sage Handbook of Qualitative Research, 4th Edition. Thousand Oaks, CA: Sage Publications.

Forsyth, Ann. 2015. "What is a walkable place? The walkability debate in urban design." Urban Design International 20(4):274-292.

Frank, Lawrence D. and Peter O. Engelke. 2001. "The Built Environment and Human Activity Patterns: Exploring the Impacts of Urban Form on Public Health." Journal of Planning Literature 16(2):202-216.

Fuguitt, G. V. and D. L. Brown. 1990. "Residential preferences and population redistribution: 72- 1988." Demography 27:589-600.

Galea, Sandro, Jennifer Ahern, Sasha Rudenstine, Zachary Wallace, David Vlahov. 2005. "Urban built environment and depression: a multilevel analysis." Journal of Epidemiology and Community Health 59:822-827.

Gidlöf-Gunnarsson, A., and E. Öhrström. 2007.“Noise and Well-Being in Urban Residential Environments: The Potential Role of Perceived Availability to Nearby Green Areas.” Landscape and Urban Planning 83(2-3):115-126.

Glaeser, E. 2011. Triumph of the City: How Our Greatest Invention Makes us Richer, Smarter, Greener, Healthier, and Happier. New York, NY: Penguin Press.

Grahn, P., and U. K. Stigsdotter. 2010. "The relation between perceived sensory dimensions of urban green space and stress restoration." Landscape and Urban Planning 94:264-275. 
Grinde, B., and G. G. Patil. 2009. "Biophilia: Does Visual Contact with Nature Impact on Health and Well- Being?" International Journal of Environmental Research and Public Health 6(9):2332-2343.

Heath, Gregory W., Diana C. Parra, Olga L. Sarmiento, Lars Bo Anderson, Neville Owen, Shifalika Goenka, Felipe Montes, and Ross C. Brownson. 2012. "Evidence-based intervention in physical activity: lessons from around the world." Lancet 380:272-281.

Helliwell, John F., Hugh Shiplett, and Christopher P. Barrington-Leigh. 2018. "How Happy are your Neighbours? Variation in Life Satisfaction Among 1200 Canadian Neighbourhoods and Communities." National Bureau of Economic Research. Cambridge, MA.

Helliwell, John F. and Robert D. Putnam. 2004. "The social context of well-being." Philosophical Transactions of the Royal Society of London. Series B: Biological Sciences 359(1449):1435-1446.

Helliwell, John F. and Shun Wang. 2010. "Trust and well-being." International Journal of Wellbeing 1:42-78.

Holland, L. 2004. "Diversity and Connections in Community Gardens: A Contribution to Local Sustainability." Local Environment 9(3):285-305.

Huffington Post. 2017. “Canada Makes 1st Appearance On Least-Stressed City List.” Retrieved December 27, 2018 (https://www.huffingtonpost.ca/2017/09/14/least-stressedcities_a_23209127/).

Hulchanski, J. David. 2007. "The Three Cities Within Toronto.” Cities Centre, University of Toronto: Toronto, ON.

Iamundo, Gabriella. 2017. "These Are Canada's Most Stressed Out Provinces." Retrieved December 27, 2018 (https://www.narcity.com/news/these-are-the-most-stressed-outprovinces-in-canada).

Jackson, Laura E. 2003. "The relationship of urban design to human health and condition." Landscape and Urban Planning 64:191-200.

Jaffe, Eric. 2015. “The (Pretty Much Totally) Complete Health Case for Urban Nature.” CityLab. Retrieved January 19, 2019 from https://www.citylab.com/environment/2015/10/thepretty-much-totally-complete-health-case-for-urban-nature/411331/.

Joffe, Helene and Nicholas Smith. 2016. "City dweller aspirations for cities of the future: How do environmental and personal wellbeing feature?" Cities 59:102-112. 
Kent, Jennifer L. and Susan Thompson. 2014. "The Three Domains of Urban Planning for Health and Well-being." Journal of Planning Literature 29(3):239-256.

Kenzer, Marina. 1999. "Healthy cities: A guide to the literature." Environment and Urbanization 11(1):201-220.

Kingsley, J., M. Townsend, and C. Henderson-Wilson. 2009. "Cultivating Health and Wellbeing: Members' Perceptions of the Health Benefits of a Port Melbourne Community Garden." Leisure Studies 28(2):207-219.

Koohsari, Mohammad J., Hannah Badland, and Billie Giles-Corti. 2013. “(Re)Designing the built environment to support physical activity: Bringing public health back into urban design and planning." Cities 35:294-298.

Kyttä, Marketta, Anna Broberg, Mohammed Haybatollahi, Kaisa Schmidt-Thomé. 2016. “Urban happiness: context-sensitive study of the social sustainability of urban settings." Environment and Planning B: Planning and Design 43:34-57.

Lansing, John B. and Robert W. Marans. 1969. "Evaluation of Neighbourhood Quality.” Journal of the American Institute of Planners 3:195-199.

Lehman \& Associates. 1995. "Urban Density Study" Toronto: Ontario Office for the Greater Toronto Area.

Leyden, Kevin M., Abraham Goldberg, and Philip Michelbach. 2011. "Understanding the Pursuit of Happiness in Ten Major Cities.” Urban Affairs Review 47(6) 861:888.

Litman, Todd. 2018. "Urban Sanity: Understanding Urban Mental Health Impacts and How to Create Saner, Happier Cities.” Victoria Transport Policy Institute. Victoria, British Columbia.

Lovasi, G. S., O. Schwartz-Soicher, J. W. Quinn, D. K. Berger, K. M. Neckerman, and R. Jaslow. 2013. "Neighborhood safety and green space as predictors of obesity among preschool children from low-income families in New York City." Preventive Medicine 57(3): 189-193.

Maas, J., P. Spreeuwenberg, M. Van Winsum-Westra, R. A. Verheij, S. de Vries, and P. P. Groenewegen. 2009. "Is Green Space in the Living Environment Associated with People's Feelings of Social Safety.” Environment and Planning A 41(7):1763-1777.

Mehta, Vikas. 2007. "Lively Streets: Determining Environ- mental Characteristics to Support Social Behaviour.” Journal of Planning Education and Research 27(2):165-187. 
Mehta, Vikas. 2008. "Walkable streets: pedestrian behaviour, perceptions and attitudes." Journal of Urbanism 1(3):217-245.

Mehta, Vikas. 2009. "Look Closely and You Will See, Listen Carefully and You Will Hear: Urban Design and Social Interaction on Streets." Journal of Urban Design 14(1):29-64.

Mills, Albert J., Gabrielle Durepos, and Elden Wiebe. 2010. “Coding: Selective Coding” in Encyclopedia of Case Study Research. Los Angeles: Sage Publications.

Mitchell, R., and F. Popham. 2007. Greenspace, urbanity and health: Relationships in England. Journal of Epidemiology \& Community Health 61:681-683.

Montgomery, Charles. 2013. Happy City: Transforming Our Lives Through Urban Design. Canada: Doubleday Canada.

Mouratidis, Kostas. 2018. "Built environment and social well-being: How does urban form affect social life and personal relationships?" Cities 74:7-20.

Mouratidis, Kostas. 2018. "Is compact city livable? The impact of compact versus sprawled neighbourhoods on neighbourhood satisfaction." Urban Studies 55(11):2408-2430.

Newbury, Joanna, Louise Arseneault, Avshalom Caspi, Terrie E. Moffitt, Candice L. Odgers, and Helen L. Fisher. 2016. "Why Are Children in Urban Neighborhoods at Increased Risk for Psychotic Symptoms?” Schizophrenia Bulletin 42:6(1):1372-1383.

Oldenburg, Ray. 1989. The great good place: Cafes, coffee shops, community centers, beauty parlours, general stores, bars, hangouts, and how they get you through the day. New York: Marlowe.

Olmsted, Frederick Law. 1865. Yosemite and the Mariposa Grove: A Preliminary Report, 1865. California, USA: Yosemite Association.

Okulicz-Kozaryn, Adam and Joan Maya Mazelis. 2018. "Urbanism and happiness: A test of Wirth's theory of urban life." Urban Studies 55(2):349-364.

Pacione, Michael. 2003. "Urban environmental quality and human wellbeing - a social geographical perspective." Landscape and Urban Planning 65(1-2):19-30.

Park, Alice. 2011. "Stressed in the City: How Urban Life May Change Your Brain." Retrieved December 27, 2018 (http://healthland.time.com/2011/06/22/stressed-in-the-city-howurban-life-may-change-your-brain/). 
Peen, J., R. A. Schoevers, A. T. Beekman, and J. Dekker. 2010. "The current status of urban-rural differences in psychiatric disorders.” Acta Psychiatr Scand 121:84-93.

Porteus, J. Douglas. 1971. "Design with people: The quality of the urban environment." Environment and Behaviour 3(2):155-177.

Putnam, Robert D. 2000. Bowling alone: The collapse and revival of American community. New York, NY: Simon \& Schuster.

Rapoport, Amos. 1987. "Pedestrian street use: Culture and perception." In Public streets for public use, Anne Moudon, ed. New York: Van Nostrand Reinhold.

Roberts, Marion. 2007. "Sharing Space: Urban Design and Social Mixing in Mixed Income New Communities." Planning Theory \& Practice 8(2):183-204.

Ross, Catherine L. and Anne E. Dunning. 1997. "Land Use Transportation Interaction: An Examination of the 1995 NPTS Data." U.S. Department of Transportation, Federal Highway Administration.

Simmel, Georg. 1903. "The Metropolis and Mental Life.”

Speck, Jeff. 2012. Walkable City. New York, NY: Farrar, Strauss and Giroux.

Smith, C.J. 1977. "Geography and Mental Health.” Association of American Geographers: Washington, DC.

Smith, Lydia. 2018. “All the Ways Living in a City Messes With Your Mental Health.” Retrieved December 27, 2018 (https://tonic.vice.com/en_us/article/qvnngm/all-the-ways-living-ina-city-messes-with-your-mental-health).

Srivastava, Kalpana. 2009. "Urbanization and mental health.” Ind Psychiatry J 18(2):75-76.

Stofan, John, Loretta DiPietro, Dorothy Davis, Harold Kohl, and Steven Blair. 1998. "Physical activity patterns associated with cardiorespiratory fitness and reduced mortality: The aerobics center longitudinal study." American Journal of Public Health 88(12): 1807-1812.

Sugiyama, T., and C. Ward Thompson. 2007. "Older People's Health, Outdoor Activity and Supportiveness of Neighbourhood Environments." Landscape and Urban Planning 83(23):168-175.

Thompson, Susan and Jennifer Kent. 2014. "Connecting and strengthening communities in place for health and wellbeing." Australian Planner 51(3):260-271. 
Transportation Research Board. 2005. "Does the Built Environment Influence Physical Activity? Examining the Evidence." Washington, DC: Transportation Research Board.

UK Department of Health. 2014. "The Relationship Between Wellbeing and Health." Retrieved February 3, 2019 from https://assets.publishing.service.gov.uk/government/uploads/ system/uploads/attachment_data/file/295474 The_relationship_between_wellbeing_and_ health.pdf

von Szombathely, Malte, Muriam Albrecht, Dejan Antanaskovic, Jobst Augustin, Matthias Augustin, Benjamin Bechtel, Thomas Bürk, Jana Fischereit, David Grawe, Peter Hoffmann, Giedrius Kaveckis, Anne Caroline Krefis, Jürgen Oßenbrügge, Jürgen Scheffran, and K. Heinke Schlünzen. 2017. "A Conceptual Modeling Approach to Health-Related Urban Well-Being." Urban Science 1(17):1-18.

Wakefield, S., F. Yeudall, C. Taron, J. Reynolds, and A. Skinner. 2007. "Growing Urban Health: Community Gardening in South-East Toronto." Health Promotion International 22(2): 92-101.

White, Mathew P., Ian Alcock, Benedict W. Wheeler, and Michael H. Depledge. 2013. "Would You Be Happier Living in a Greener Urban Area. A Fixed-Effects Analysis of Panel Data." Psychological Science 24(6):920-928.

Williams, P., and B. Pocock. 2010. "Building ‘Community' for Different Stages of Life: Physical and Social Infrastructure in Master Planned Communities." Community, Work and Family 13(1):71-87.

Wilson, J., and G. Kelling. 1984. "Broken Windows.” The Atlantic Online March, 1-9.

Woodgate, R. L., and O. Skarlato. 2015. "It is about being outside: Canadian youth's perspectives of good health and the environment." Health \& Place 31:100-110.

World Health Organization. 1998. "The WHO Health Promotion Glossary." Retrieved January 27, 2019 from https://www.who.int/healthpromotion/about/HPG/en/.

World Health Organization. 2006. "Constitution of the World Health Organization." Retrieved January 28, 2019 from https://www.who.int/governance/eb/who_constitution_en.pdf.

Yu, Ruby, Osbert Cheung, Kevin Lau, and Jean Woo. 2017. "Associations between Perceived Neighbourhood Walkability and Walking Time, Wellbeing, and Loneliness in Community-Dwelling Older Chinese People in Hong Kong." International Journal of Environmental Research and Public Health 14(10):1-15. 